Technical Paper 142

DEPARTMENT OF THE INTERIOR

FRANKLIN K. LANE, SECRETARY

BUREAU OF MINES

VAN. H. MANNING, DIREctoR

\title{
VAPOR PRESSURES OF VARIOUS COMPOUNDS AT LOW TEMPERATURES
}

BY

G. A. BURRELL AND I. W. ROBERTSON

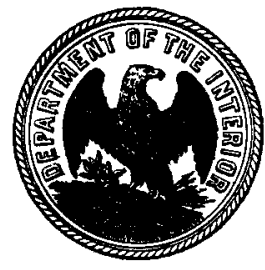

WASHINGTON

GOVERNMENT PRINTING OFFICE 1916

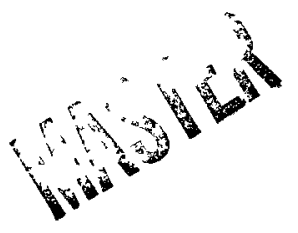

1

'DISTRIBUTION OF THIS DOCUMENT IS UNLIMITED 


\section{DISCLAIMER}

This report was prepared as an account of work sponsored by an agency of the United States Government. Neither the United States Government nor any agency Thereof, nor any of their employees, makes any warranty, express or implied, or assumes any legal liability or responsibility for the accuracy, completeness, or usefulness of any information, apparatus, product, or process disclosed, or represents that its use would not infringe privately owned rights. Reference herein to any specific commercial product, process, or service by trade name, trademark, manufacturer, or otherwise does not necessarily constitute or imply its endorsement, recommendation, or favoring by the United States Government or any agency thereof. The views and opinions of authors expressed herein do not necessarily state or reflect those of the United States Government or any agency thereof. 


\section{DISCLAIMER}

Portions of this document may be illegible in electronic image products. Images are produced from the best available original document. 
The Bureau of Mines, in carrying out one of the provisions of its organic act-to disseminate information concerning investigations made-prints a limited free,edition of each of its publications.

When this edition is exhausted copies may be obtained at cost price only through the Superintendent of Documents, Government Printing Office, Washington, D. C.

The Superintendent of Documents is not an official of the Bureau of Mines. His is an entirely separate office and he should be addressed:

SUPERINTENDENT OF Documents,

\section{Government Printing Office,}

Washington, $D . C$.

The general law under which publications are distributed prohibits the giving of more than one copy of a publication to one person. The price of this publication is 5 cents.

First edition. August, 1916. 


\section{CONTENTS.}

Introduction

Apparatus used and method of conducting tests........................... 5

Method of using manometer................................. 7

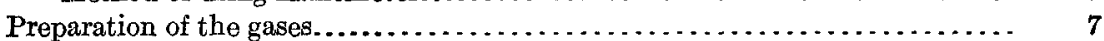

Ethylene and ethane......................................... 7

Propane, propylene, and butane............................. 9

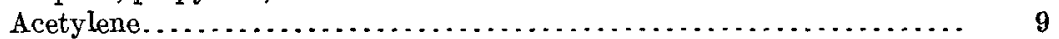

Ammonia, sulphur dioxide, and nitrous oxide................... 9

Other precautions to insure that the gases were pure............... 10

Temperature measurements.................................... 10

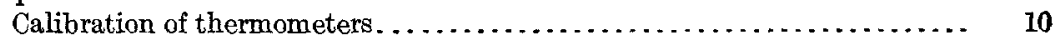

Method of calibrating the thermometers against the melting points of mercury, chloroform, and ice..............................

Calibration against carbon dioxide, ether, carbon bisulphide, and

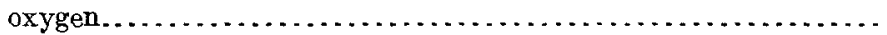

Results of vapor-pressure measurements......................... 13

Calculation of the vapor-pressure curves.......................... 18

Heat of evaporation of ethane and ethylene........................ 19

Vapor-pressure measurements compared with those obtained by other investi-

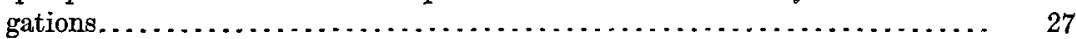

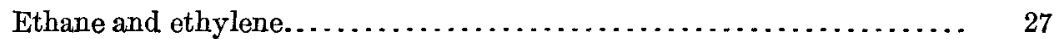

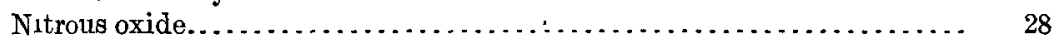

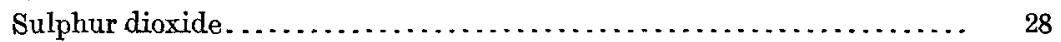

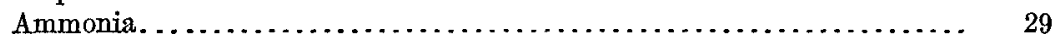

Application of results to separation of gaseous mixtures................ 29

Publications on petroleum technology ......................... 31

Publications that may be obtained only through the Superintendent of Documents..................................................... 


\section{ILLUSTRATIONS.}

Figure 1. Apparatus for vapor-pressure measurements.................

2. Manometer for measuring vapor pressures of gases................

3. Vapor-pressure curves for ethylene and ethane, showing pressure plotted as a function of the temperature....................

4. Vapor-pressure curves for propylene, propane, and butane, showing pressure plotted as a function of the temperature...............

5. Vapor-pressure curves for acetylene, ammonia, and isobutane, showing pressure plotted as a function of the temperature...........

6. Vapor-pressure curves for nitrous oxide and sulphur dioxide, showing pressure plotted as a function of the temperature..........

7. Vapor-pressure curves for ethylene and ethane, showing common logarithm of pressure plotted as a function of the reciprocal of the

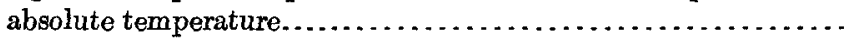

8. Vapor-pressure curves for propylene, propane, and normal butane, showing common logarithm of pressure plotted as a function of the reciprocal of the absolute temperature.....................

9. Vapor-pressure curves for acetylene, ammonia, and is obutane, showing common logarithm of pressure plotted as a function of the reciprocal of the absolute temperature....................

10. Vapor-pressure curves for nitrous oxide and sulphur dioxide, showing common lozarithm of pressure plotted as a function of the reciprocal of the absolute temperature.................... 


\title{
VAPOR PRESSURES OF VARIOUS COMPOUNDS AT LOW TEMPERATURES.
}

\author{
By G. A. Burrell and I. W. Robertson.
}

\section{INTRODUCTION.}

The authors of this report in their work on the condensation of the constituents in natural gas, and in studying the separation of gas mixtures by fractional distillation, made vapor-pressure measurements of gases at low temperatures. Among the compounds for which the pressures at such temperatures either had not been determined, or had been determined only within limited ranges of temperature were ethylene, propylene, isobutylene, ethane, propane, isobutane, sulphur dioxide, nitrous oxide, ammonia, and acetylene. This paper presents the results of vapor-pressure measurements of the compounds mentioned at temperatures below the normal boiling point and at pressures ranging from $760 \mathrm{~mm}$. to $1 \mathrm{~mm}$.

\section{APPARATUS USED AND METHOD OF CONDUCTING TESTS. $a$}

The apparatus with which the measurements were made is shown in figures 1 and 2. The gas whose vapor pressure was to be measured was confined in the glass bulb $b$ (fig. 1), which communicated on one side with a manometer and on the other side with a Töpler mercury pump. The liquid used for the bath, gasoline from natural gas, was confined in a Dewar flask $f$, which was about $35 \mathrm{~cm}$. high and $10 \mathrm{~cm}$. wide, inside measurements. The flask was not silvered, hence temperatures on a pentane thermometer could be observed through its walls. A small pump $e$, driven by a small electric motor, stirred the bath vigorously and efficiently by drawing the gasoline in at the base and discharging it through four holes in the casing. The temperature was registered by a pentane thermometer $c$. To cool the bath, liquid air was forced from the Dewar flask $f$ through the tube $h$ in to a glass test tube $d$, which was open at the top and dipped into the bath. This arrangement for cooling liquids or gases and maintaining them at a constant temperature was devised by Henning. ${ }^{b}$ One end of the double-walled and evacuated tube $h$ passed through the two-hole

a The apparatus was constructed in the laboratory of the Bureau of Mines by F. E. Donath, glassblower and instrument maker, and W. F. Hausstein, foreman instrument maker.

b Henning, F., Ein Thermostat fïr tiefe Temperaturen: Ztschr. Instrumentkunde, vol. 33, February, 1913, p. 33. 
stopper $k$ and dipped beneath the surface of the liquid air in the flask $f$. Another glass tube, not immersed in liquid air, passed through the stopper $k$ and was joined by a rubber tube to a glass tube $g$, which dipped into a cylinder of water $i$. By lowering or raising the tube $g$ the pressure exerted in the flask $f$ could be changed and the quantity of liquid air forced through $h$ into $d$ could be varied. The depth of immersion of the tube $g$ could be so adjusted that just enough liquid air would be forced into $d$ to compensate for the heat absorbed by the bath, thereby maintaining the temperature of the bath constant within 0.04 degree, although the temperature could

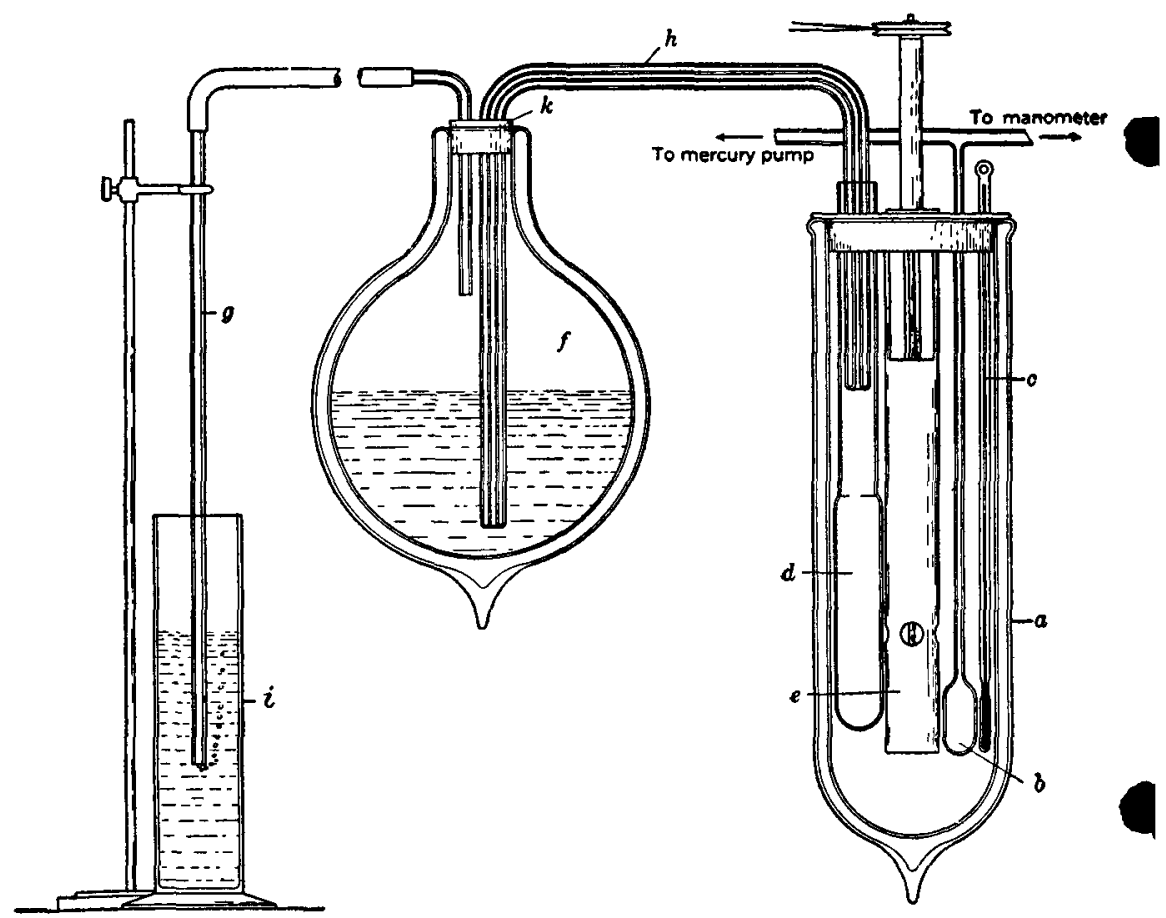

FIGURE 1.-Apparatus for vapor-pressure measurements.

not be measured directly with that degree of precision. At temperatures close to the normal boiling point of ethane the temperature changes, however, about 4 degrees for each $100 \mathrm{~mm}$. change in pressure, or 0.04 degree per mm., and no trouble was experienced in maintaining pressures constant to $1 \mathrm{~mm}$. pressure close to the boiling point of ethane, or other liquid gas tested, for as long as 15 minutes, the maximum length of time that the bath was kept at constant temperature during a single observation.

The gasoline used for the bath was "casing-head" gasoline obtained . at a plant where gasoline is extracted from natural gas by subjecting it to a pressure of 250 pounds per square inch and cooling it at ordi- 
nary temperatures. A steel tank, such as is used for confining gases under heavy pressure, was shipped to the plant, where it was filled under pressure with the gasoline. This condensate contained a large proportion of liquid butane and propane, and some of the constituents of ordinary gasoline, such as pentane and hexane, and did not jelly when the lighter fractions were used until a temperature of $-175^{\circ} \mathrm{C}$. was reached.

\section{METHOD OF USING MANOMETER.}

Two views of the manometer are shown in figure 2 . In most respects it is similar to one described by Germann. ${ }^{a}$

The glass parts were thoroughly cleaned and dried and mercury that had been purified by the method suggested by Hulett ${ }^{b}$ was poured into the level bottle $f$. The bottle $f$ was raised high enough to force mercury into the capillary tube $b$ and the reservoir $c$, and then lowered, whereupon the mercury column fell, leaving a mercury seal in tubes $b$ and $c$ and a vacuum above the column in tube $a$. The precaution recommended by Germann, to clear the space above the mercury of traces of air, was followed as follows: Several days after the manometer had been filled, a water pump was attached to the mercury trap $h$ and the trace of air that had accumulated in the tube $a$ was removed. The tubes $d$ and $e$ were filled with soda lime. The scale of the manometer, which was made of steel and graduated in $0.5 \mathrm{~mm}$., was checked against a cathetometer having a rod of carefully ground steel which carried a scale divided into millimeters and was fitted with a vernier to read to $0.1 \mathrm{~mm}$., and also against a precision barometer.

\section{PREPARATION OF THE GASES.}

\section{ETHYLENE AND ETHANE.}

Ethylene was prepared by heating a mixture of sulphuric acid and alcohol at a temperature of $165^{\circ} \mathrm{C}$. The gas evolved was passed through caustic potash and phosphorus pentoxide, cooled at the temperature of liquid air, and the air in the gas, with any carbon monoxide or hydrogen that had been formed in the reaction, was withdrawn with a Töpler pump. The method of purifying gases by fractional distillation at low temperatures and pressures has been fully described in Technical Paper 104. ${ }^{c}$

\footnotetext{
a Germann, A. F. O., A modifed precision barometer: Jour. Am. Chem. Soc., vol. 36, December, 1914, pp. 2456, 2459.

b Hulett, G. A., The distillation of amalgams and the purification of mercury: Phys. Rev., vol. 33, 1911, p. 307.

c Burrell, G. A., Seibert, F. M., and Robertson, I. W., Analysis of natural gas and illuminating gas by iractional distillation at low temperatures and pressures: Tech. Paper 104, Bureau of Mines, 1915, 41 pp.
} 


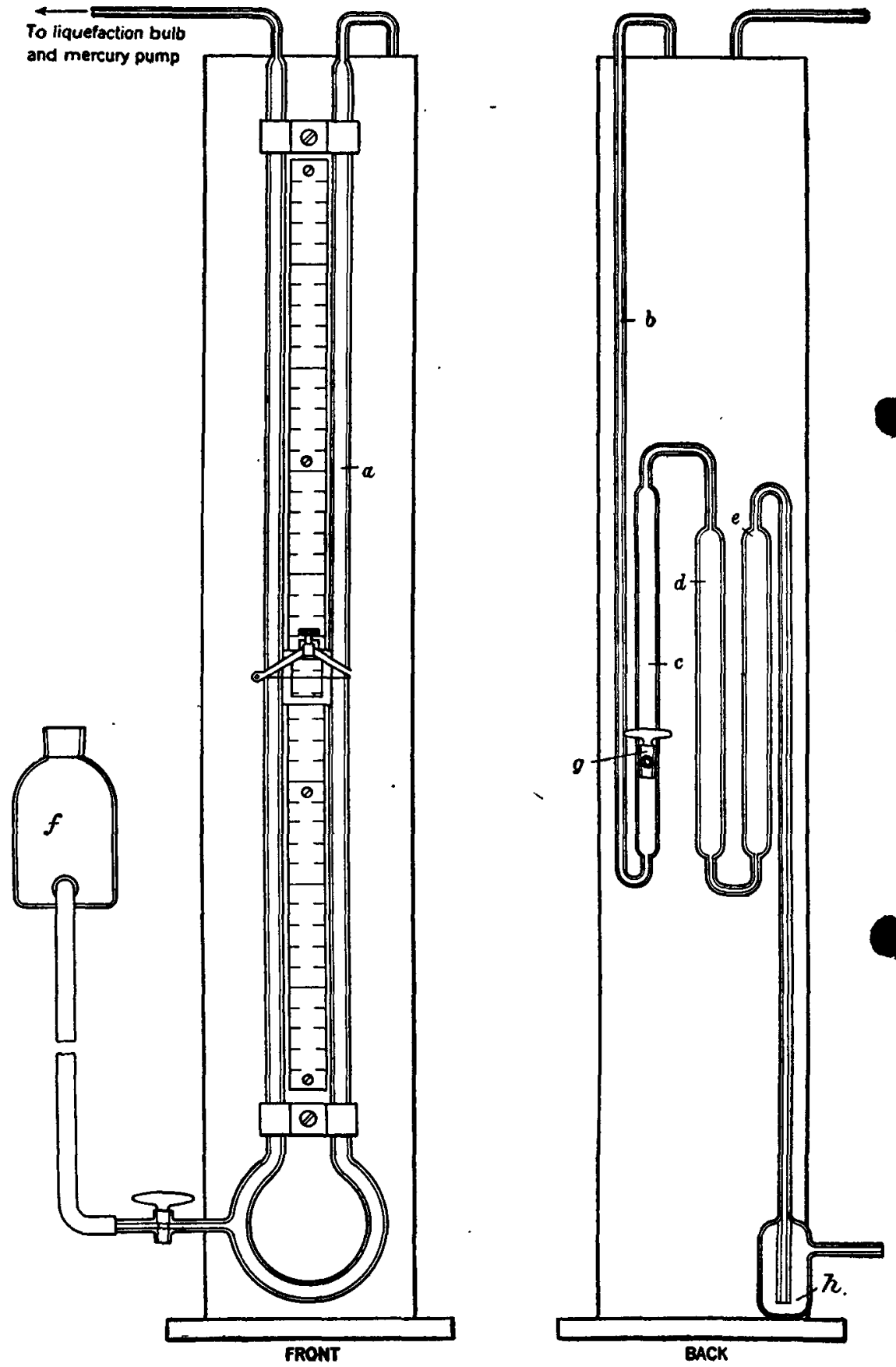

Figure 2.-Manometer for measuring vapor pressures of gases. 
Fractionation at the temperature of liquid air was repeated until no more gas could be removed with the pump. The gas was then further fractionated at a temperature not higher than $-140^{\circ} \mathrm{C}$. At this temperature ethylene was withdrawn with the pump, and any traces of water vapor or other gases having boiling points much higher than that of ethylene remained frozen.

Ethane was prepared by the electrolysis of a saturated solution of sodium acetate, and was purified in essentially the same manner as the ethylene.

PRopaNe, PROPYlENe, AND BUtaNe.

Propane was prepared by the action of propyl iodide on a zinccopper couple. It was purified by fractional distillation in a vacuum at the temperature of liquid air to rid it of air or other substances of high vapor pressure at that temperature, and at a temperature of $-110^{\circ} \mathrm{C}$. to remove water vapor and other substances whose vapor pressures are practically negligible at $-110^{\circ} \mathrm{C}$. Phosphorus pentoxide was also used to remove water vapor.

Propylene was prepared by dropping propyl alcohol on phosphorus pentoxide at ordinary temperatures.

Normal butane was prepared by the action of normal butyl iodide, and isobutane by the action of isobutyl iodide, on a zinc and copper couple. Both the butanes and the propylene were purified in essentially the same manner as the propane.

\section{ACETYLENE.}

Acetylene was prepared by the action of water on calcium carbide. The gas evolved was passed through caustic potash solution and then dried over phosphorus pentoxide. Next it was repeatedly fractionated at the temperature of liquid air to remove air and other gases of high vapor pressure at that temperature, and then was fractionated several times at temperatures of $-120^{\circ}$ to $-110^{\circ} \mathrm{C}$., to distill the acetylene from water vapor or other gases whose vapor pressure is practically nil at those temperatures.

\section{AMMONIA, SULPHUR DIOXIDE, AND NITROUS OXIDE.}

Ammonia was prepared by distilling the gas from C. P. ammonia water. The ammonia was purified by repeated distillations at low temperatures.

Sulphur dioxide was prepared by the action of sulphuric acid on copper. The sulphur dioxide was bubbled through water to remove sulphur trioxide and thoroughly fractionated at the temperature of liquid air to remove atmospheric air or other gases of high vapor $43863^{\circ}-16-2$ 
pressure at that temperature, and at temperatures between $-70^{\circ}$ and $-100^{\circ} \mathrm{C}$. to remove water vapor and other gases of negligible pressure at those temperatures.

Nitrous oxide was prepared by heating ammonium nitrate. The gas evolved was passed through caustic potash solution and sulphuric acid and then thoroughly purified by fractionation at low temperatures.

OTHER PRECAUTIONS TO INSURE THAT THE GASES WERE PURE.

In purifying the gases the fractionation was carried to the point where all of the final sample of gas distilled within a temperature range of $0.2^{\circ} \mathrm{C}$. or less. As a further precaution each gas was cooled to the temperature of liquid air, after it had been introduced into the vapor-pressure bulb, and the apparatus evacuated to make sure that air had not been trapped in the transfer. As a check on the purity of the gas, part of it was allowed to boil off during the vaporpressure measurements, and the measurements were repeated on the remaining part. Also pressure observations were made with a rising and falling mercury level in the manometer.

\section{TEMPERATURE MEASUREMENTS.}

It was originally intended to measure temperatures with a platinum resistance thermometer, but so much delay was experienced in obtaining the necessary equipment that it was decided to perform the work with pentane thermometers. With these thermometers temperatures as low as $-195^{\circ} \mathrm{C}$. could be measured. The scale divisions were 1 degree each, but were so widely spaced that two different observers could easily agree within 0.2 degree as to any particular temperature, and in most cases to within 0.1 degree.

Holborn, ${ }^{a}$ who devised the pentane thermometer found that if followed the fluctuations of a hydrogen thermometer, in most cases to within 0.1 degree if properly used.

\section{CALIBRATION OF THERMOMETERS.}

The authors calibrated the pentane thermometers against certain fixed points in a scale of boiling and melting points established by Henning. ${ }^{b}$ This scale, together with observations by others, follows. With the exception of Siemens's ${ }^{c}$ values, the data given in the table are all cited by Henning.

a Holborn, L., Untersuchungen über Platinwiderstände und Petrolätherthermometer: Ann. der Physik, Bd. 6, 1901 , p. 242.

b Henning, F., Die Fixierung der Temperaturskala zwischen 0 und $-193^{\circ}$ : Ann. der Physik, 1913, Bd. 43, p. 294.

c Siemens, H. v., Über Dampfdruckmessungen und Thermometrie bei tiefen Temperaturen: Ann. der Physik, Bd. 42, 1913, pp. 871-888. 
Boiling and melting points of different substances as determined by different observers.

\begin{tabular}{|c|c|c|c|c|c|c|c|}
\hline \multirow{2}{*}{ Substance $a$} & \multicolumn{7}{|c|}{ Boiling or melting point as determined by- } \\
\hline & Hennmg & $\underset{\text { mans }}{\text { Timmer- }}$ & Baly & Dewar & Travers & Onnes & Stemens. \\
\hline 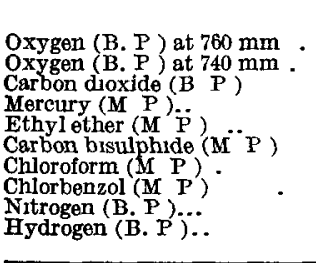 & 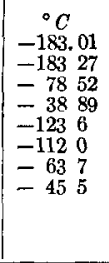 & $\begin{array}{ll}{ }^{\circ} C \\
\\
\\
-\quad 38 & 6 \\
-123 & 3 \\
-111 & 6 \\
-63 & 3 \\
-45 & 0\end{array}$ & $\begin{array}{c}{ }^{\circ} \mathrm{C} \\
-1819\end{array}$ & ${ }^{\circ} C$ & $\begin{array}{c}{ }^{\circ} C \\
-1828\end{array}$ & $\begin{array}{c}{ }^{\circ} C \\
-18299\end{array}$ & $\begin{array}{r}{ }^{\circ} \mathrm{C} \\
-18299 \\
=7844 \\
-38.77 \\
\because-112.16 \\
\cdot \cdots \\
-195.84 \\
-252.68\end{array}$ \\
\hline
\end{tabular}

a $\mathrm{B} \quad \mathrm{P}=$ boiling point, $\mathrm{M} \quad \mathrm{P}=$ melting point

It will be observed that the results of Henning, Onnes, and Siemens agree fairly well. For the boiling point of oxygen the agreement is striking, the variation being only 0.02 degree, which is the limit of precision obtainable with the hydrogen thermometer.

The pentane thermometers used by the authors were calibrated at seven points: The melting points of mercury, ohloroform, and ice, the normal boiling point of carbon dioxide, the melting points of carbon bisulphide and ethyl ether, and at $-183.27^{\circ} \mathrm{C}$., the temperature of liquid oxygen boiling at $740 \mathrm{~mm}$. The carbon dioxide was prepared in two ways: (1) Carbon dioxide, such as is furnished commercially in steel tanks, was thoroughly fractionated at low temperatures and passed over phosphorus pentoxide to remove water vapor; (2) carbon dioxide was prepared by the action of dilute sulphuric acid on potassium bicarbonate, and thoroughly purified in the same way as the commercial carbon dioxide obtained from the tank.

The ethyl ether and carbon bisulphide were Kahlbaum's purest reagents. Their melting points were not changed by redistilling them over phosphorus pentoxide.

The oxygen was prepared by heating Kahlbaum's potassium permanganate in an evacuated hard-glass tube, discarding the first gas that came off, then liquefying the remainder with liquid air and pumping the liquefied oxygen into another container. For regulating the temperature a bath of liquid oxygen was used when calibrating against the vapor pressure of the liquified oxygen obtained in the experiment.

The chloroform used was Kahlbaum's purest reagent. Mercury was prepared by fractionating it after the method of Hulett. ${ }^{a}$ No changes in the melting points of these substances were found by additional fractionation of them.

a Hulett, G. A., The distillation of amalgams and the purification of merctry Phys. Rev., vol. 33, 1911, p. 307. 
METHOD OF CALIBRATING THE THERMOMETERS AGAINST THE MELTING POINTS OP MERCURY, CHLOROFORM, AND ICE.

In calibrating the thermometers against the melting point of mercury, about 15 c. c. of mercury was placed in a test tube and immersed in a bath of gasoline at a temperature a few degrees below the melting point of mercury. Then the temperature of the bath was allowed to rise slowly, and at the melting point of mercury the temperature, of course, became stationary until all of the mercury had melted. The mercury was again distilled and the procedure repeated, with the same results. The following table shows the time at which temperature readings were made, the temperature of the bath, and readings as made with two different pentane thermometers. From the values so found the thermometers were corrected according to the melting point of mercury as given by Henning.

Calibration of pentane thermometers against the melting point of mercury.

FIRST TRIAL, FRESH MERCURY.

\begin{tabular}{|c|c|c|c|c|c|}
\hline \multirow{2}{*}{ Time. } & \multicolumn{2}{|c|}{$\begin{array}{l}\text { Temperature as } \\
\text { shown by- }\end{array}$} & \multirow{2}{*}{ Time. } & \multicolumn{2}{|c|}{$\begin{array}{l}\text { Temperature as } \\
\text { shown by- }\end{array}$} \\
\hline & $\begin{array}{l}\text { Ther- } \\
\text { mometer } \\
\text { No. } 707 \text {. }\end{array}$ & $\begin{array}{l}\text { Ther- } \\
\text { mometer } \\
\text { No. 504. }\end{array}$ & & $\begin{array}{l}\text { Ther- } \\
\text { mometer } \\
\text { No. } 707 \text {. }\end{array}$ & $\begin{array}{l}\text { Ther- } \\
\text { mometer } \\
\text { No. 504. }\end{array}$ \\
\hline $\begin{array}{c}a . m . \\
10.15 \\
10.18 \\
10.23 \\
10.26 \\
10.27 \\
10.28 \\
10.29 \\
10.30 \\
10.32 \\
10.34\end{array}$ & $\begin{array}{l}{ }^{\circ} \mathrm{C} . \\
50.0 \\
47.0 \\
43.0 \\
41.0 \\
40.0 \\
39.0 \\
38.8 \\
38.7 \\
38.6 \\
39.5\end{array}$ & $\begin{array}{r}{ }^{\circ} C . \\
47.8 \\
44.6 \\
41.0 \\
39.0 \\
38.0 \\
37.1 \\
37.0 \\
36.9 \\
36.8 \\
36.7\end{array}$ & $\begin{array}{l}a . m . \\
10.36 \\
10.38 \\
10.39 \\
10.40 \\
10.41 \\
10.42 \\
10.43 \\
10.44 \\
10.45\end{array}$ & $\begin{array}{r}{ }^{\circ} C . \\
a 38.4 \\
a 38.4 \\
\text { a } 38.4 \\
\text { a } 38.4 \\
38.3 \\
38.0 \\
37.6 \\
37.3 \\
36.8\end{array}$ & $\begin{array}{r}\circ C . \\
a 36.5 \\
a 36.5 \\
a 36.5 \\
a 36.5 \\
36.4 \\
36.1 \\
35.7 \\
35.5 \\
35.0\end{array}$ \\
\hline
\end{tabular}

SECOND TRIAL, REDISTILLED MERCURY.

\begin{tabular}{|r|r|r|r|r|r|}
\hline 11.00 & 40.0 & 38.0 & 11.11 .5 & a 38.5 & $a 36.6$ \\
11.01 & 39.4 & 37.5 & 11.12 & a 38.5 & a 36.6 \\
11.02 & 39.3 & 37.4 & 11.12 .5 & $\mathbf{a} 38.5$ & $a 36.6$ \\
11.04 & 39.1 & 37.2 & 11.13 & 38.3 & 36.4 \\
11.06 & 39.0 & 37.1 & 11.14 & 38.0 & 36.1 \\
11.08 & 38.8 & 36.9 & 11.15 & 37.6 & 35.8 \\
11.10 & 38.6 & 36.7 & 11.16 & 37.2 & 35.5 \\
11.11 & $a 38.5$ & a 36.6 & & & \\
\hline
\end{tabular}

a Melting point.

The thermometers were calibrated against the melting point of clorobenzene, chloroform, carbon disulphide, and ethyl ether in the same manner.

The uncorrected temperature readings, as made by the authors with the pentane thermometers, at the melting points of chloroform, mercury, and ice, are given below to show how the readings differed on two of the pentane thermometers. 
Varation in results by two pentane thermometers

\begin{tabular}{|c|c|c|c|}
\hline & & $\begin{array}{l}\text { Ther- } \\
\text { mometer } \\
\text { No } 504\end{array}$ & $\begin{array}{l}\text { Then- } \\
\text { mometer } \\
\text { No } 707\end{array}$ \\
\hline Melting point of chloroform, ${ }^{\circ} \mathrm{C}$ & - & -640 & -671 \\
\hline Melting point of mercury, ${ }^{\circ} \mathrm{C}$ & & -365 & -384 \\
\hline Melting point of ice, ${ }^{\circ} \mathrm{C}$ & & +14 & +13 \\
\hline
\end{tabular}

In addition to using pentane thermometers, a mercury thermometer calibrated by J. K. Clement, physicist of the Bureau of Mines, was used in determining the normal boiling point of normal butane.

CALIBRATION AGAINST CARBON DTOXIDE, ETHER, CARBON BISULPHIDE, AND OXYGEN.

Three different pentane thermometers, No. 504, No. 707, and No. 8161, were calibrated against carbon dioxide, ether, carbon bisulphide, and oxygen; the uncorrected readings given below show how the thermometers varied among themselves. For instance, at the normal boiling point of carbon dioxide, thermometer No. 8161 read $-77.8^{\circ}$, thermometer No. 707 read $-81.8^{\circ}$, and thermometer No. 504 read $-78.8^{\circ}$.

Temperature observations with three different pentane thermometers

\begin{tabular}{|c|c|c|c|}
\hline \multirow{2}{*}{ Substance used } & \multicolumn{3}{|c|}{$\begin{array}{c}\text { Temperature as renorded on } \\
\text { thermometer No - }\end{array}$} \\
\hline & 8161 & 707 & 504 \\
\hline $\begin{array}{l}\text { Carbon droxide, bolling point at } 760 \mathrm{~mm} a \\
\text { Carbon dioxde, bolling at } 760 \mathrm{~mm} \text { b } \\
\text { Carbon bisulphide }\left(\mathrm{M}^{\mathrm{P}}\right) \\
\text { Do } \\
\text { Ethyl ether (M P ) } \\
\text { Do } \\
\text { Oxygen, at vapor pressure of } 740 \mathrm{~mm}\end{array}$ & $\begin{aligned} &{ }^{\circ} C \\
&-778 \\
&=77 \\
&-1110 \\
&-1110 \\
& 1228 \\
& 1228\end{aligned}$ & $\begin{array}{rl}{ }^{\circ} C & \\
-81 & 8 \\
-81 & 9 \\
-114 & 0 \\
-114 & 0 \\
125 & 5 \\
125 & 5 \\
-182 & 0\end{array}$ & $\begin{array}{l}{ }^{\circ} \mathrm{C} \\
-788 \\
=786 \\
-1116 \\
-1116 \\
1235 \\
1235 \\
-1830\end{array}$ \\
\hline
\end{tabular}

$a$ Purified carbon dıoxıde prepared from sulphuric acid and potassıum carbonate

$b$ Purified commercial carbon dioxide from tank

When independent observations of the vapor pressures of different gases were made with different thermometers, as noted later, and the results corrected according to the respective callbrations of the thermometers used, it was found that the results for the same pressure were similar, thus showing that if the results were plotted, a curve drawn through intermediate readings taken at uncalibrated points on the thermometer would not vary greatly from a straight line drawn between two calibrated points.

\section{RESULTS OF VAPOR-PRESSURE MEASUREMCNTS.}

The results of vapor-pressure measurements by the authors for different substances measured at the saturation point, for temperatures below the boaling point, and at pressures ranging from $0^{\circ}$ to $760^{\circ} \mathrm{mm}$, are given in Table 1.

In readings taken near the normal boiling point of the substance tested a very small temperature change is represented by a large 
pressure change. For instance, in the case of ethane, a temperature change of 1.6 degrees (from $90.9^{\circ}$ to $89.3^{\circ}$ ) corresponds to a pressure change of $60 \mathrm{~mm}$., or 0.2 degree (the limit of accuracy with the thermometer), corresponds to a pressure variation of $7.5 \mathrm{~mm}$. In the case of ethylene a variation of 0.2 degree at the normal boiling point corresponds to about $7 \mathrm{~mm}$. At temperatures between $128.5^{\circ}$ and $133.7^{\circ} \mathrm{C}$, a change of 0.2 degree in the temperature of ethane corresponds to a pressure change of almost $1 \mathrm{~mm}$. and at the lowest temperatures given $\left(157.7^{\circ}\right.$ and $159.8^{\circ} \mathrm{C}$.) a change of $1 \mathrm{~mm}$. corresponds to 2.1 degree or 0.2 degree corresponds to $0.9 \mathrm{~mm}$.

As the limits of accuracy in the thermometer readings were 0.2 degree and of pressure readings $1 \mathrm{~mm}$., the observations at high temperature were made by adjusting the thermostat until the mercury in the manometer remained constant to within $1 \mathrm{~mm}$. and then reading the thermometer. In testing ethane at the lower temperatures (below $-128.5^{\circ} \mathrm{C}$ ) the thermostat was adjusted until the pentane thread in the thermometer remained constant to within 0.2 degree, and then the pressure was read. The same procedure was followed with the other gases, the object being to keep within the limits of error, at all times, in reading temperatures and pressures.

The thermometer measurements could be reproduced within $0.2^{\circ}$ C., and pressure readings within $1 \mathrm{~mm}$. Stem corrections on the thermometers were not necessary because the thermometers had been calibrated with the same depth of immersion as during the vapor-pressure measurements. Corrections for the expansion of the mercury in the manometer, and for the steel scale, fell within the error of experimentation.

TABLE 1 -Vapor pressures at saturation of various compounds at temperatures below the normal bouling point and pressures ranging from 0 to $760 \mathrm{~mm}$

ETHYLENE

\begin{tabular}{|c|c|c|c|c|c|c|}
\hline \multicolumn{5}{|c|}{ Temperature } & \multicolumn{2}{|c|}{ Pressure } \\
\hline By pent & ane therm & meter- & \multirow{2}{*}{\multicolumn{2}{|c|}{ Average }} & \multirow{2}{*}{$\begin{array}{c}\mathrm{Ob}- \\
\text { served }\end{array}$} & \multirow{2}{*}{$\begin{array}{l}\text { Calcu- } \\
\text { lated }\end{array}$} \\
\hline No 707. & No 8161 & No 504 & & & & \\
\hline $\begin{array}{cc}\circ C & \\
-103 & 7 \\
-104 & 8 \\
-105 & 3 \\
-106 & 8 \\
-107 & 9 \\
-111 & 0 \\
-114 & 1 \\
-118 & 2 \\
-123 & 5 \\
-132 & 0 \\
-135 & 2 \\
-139 & 5 \\
-144 & 2 \\
-149 & 3 \\
-154 & 7 \\
-159 & 8\end{array}$ & $\begin{array}{c}\cdot C \\
-1039 \\
-1054 \\
-1068 \\
-1080 \\
-1110 \\
-1141 \\
-118 \\
-123 \\
-128\end{array}$ & 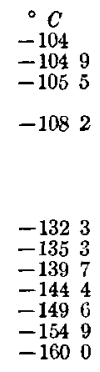 & $\begin{array}{cc}\circ C \\
-103 & 9 \\
-104 & 8 \\
-105 & 4 \\
-106 & 8 \\
-118 & 0 \\
-111 & 0 \\
-114 & 1 \\
-118 & 2 \\
-123 & 6 \\
-132 & 2 \\
-135 & 3 \\
-139 & 6 \\
-144 & 3 \\
-149 & 4 \\
-154 & 8 \\
-159 & 9\end{array}$ & $\begin{array}{rr}0 & A b s \\
169 \\
168 \\
167 \\
167 \\
166 & 3 \\
165 & 1 \\
162 & 1 \\
159 & 0 \\
154 & 9 \\
149 & 5 \\
140 & 9 \\
137 & 8 \\
133 & 5 \\
128 & 8 \\
123 & 7 \\
118 & 3 \\
113 & 2\end{array}$ & $\begin{array}{r}M m \boldsymbol{h g} \\
760 \\
730 \\
700 \\
650 \\
600 \\
500 \\
400 \\
300 \\
200 \\
100 \\
75 \\
50 \\
31 \\
17 \\
9 \\
4\end{array}$ & $\begin{array}{r}M m \text { hg. } \\
760 \\
726 \\
701 \\
643 \\
595 \\
512 \\
400 \\
300 \\
200 \\
98 \\
74 \\
49 \\
30 \\
17 \\
9 \\
4\end{array}$ \\
\hline
\end{tabular}

a E rec.ung point of water on absolute scale is $2731^{\circ} \mathrm{C}$ 
TABLE 1.-Vapor pressures at saturation of various compounds at temperatures below the normal boiling point and pressures ranging from 0 to $760 \mathrm{~mm}$.-Continued.

ETHANE.

\begin{tabular}{|c|c|c|c|c|c|c|}
\hline \multicolumn{5}{|c|}{ Temperature. } & \multicolumn{2}{|c|}{ Pressure. } \\
\hline By pent & ane therm & meter- & \multirow{2}{*}{\multicolumn{2}{|c|}{ Average. }} & & \\
\hline No. 707. & No. 8161 . & No. 504. & & & & \\
\hline $\begin{array}{l}\circ C . \\
-89.3 \\
-90.8 \\
-92.2 \\
-93.7 \\
-97.0 \\
-100.4 \\
-105.2 \\
-111.4 \\
-115.3 \\
-120.3 \\
-123.1 \\
-124.0 \\
-128.4 \\
-133.6 \\
-138.9 \\
-149.4 \\
-154.6 \\
-157.7 \\
-159.8\end{array}$ & 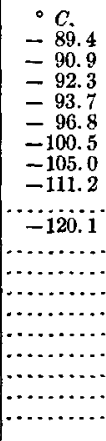 & $\begin{array}{c}\bullet C . \\
\ldots \ldots \ldots \\
\ldots \ldots \ldots \\
\ldots \ldots \\
\ldots \ldots \ldots \\
-100.6 \\
-105.1 \\
-111.3 \\
-115.4 \\
-120.2 \\
-123.2 \\
-124.2 \\
-128.7 \\
-133.9 \\
-139.2 \\
-149.7 \\
-154.7 \\
-157.8 \\
-159.9\end{array}$ & $\begin{array}{l}\circ C . \\
-89.3 \\
-90.9 \\
-92.3 \\
-93.7 \\
-96.9 \\
-100.5 \\
-105.1 \\
-111.3 \\
-115.3 \\
-120.2 \\
-123.2 \\
-124.1 \\
-128.5 \\
-133.7 \\
-139 \\
-149.5 \\
-154.6 \\
-157.7 \\
-159.8\end{array}$ & $\begin{array}{r}{ }^{\circ} A b s . \\
183.8 \\
182.2 \\
180.8 \\
179.4 \\
176.2 \\
172.6 \\
168.0 \\
161.8 \\
157.8 \\
152.9 \\
149.9 \\
149.0 \\
144.6 \\
139.4 \\
134.1 \\
123.6 \\
118.5 \\
115.4 \\
113.3\end{array}$ & $\begin{array}{r}\text { Mm. } h g . \\
760 \\
700 \\
650 \\
600 \\
500 \\
400 \\
300 \\
200 \\
150 \\
100 \\
77 \\
74 \\
49 \\
29 \\
15 \\
4 \\
3 \\
2 \\
1\end{array}$ & $\begin{array}{c}M m, h g . \\
760 \\
711 \\
651 \\
604 \\
495 \\
410 \\
307 \\
200 \\
149 \\
100 \\
77 \\
73 \\
47 \\
28 \\
15 \\
4 \\
2 \\
1.2 \\
.8\end{array}$ \\
\hline
\end{tabular}

- ACETYLENE.

\begin{tabular}{|c|c|c|c|c|c|}
\hline \multicolumn{4}{|c|}{ Temperature. } & \multicolumn{2}{|c|}{ Pressure. } \\
\hline By pent & $\begin{array}{l}\text { no ther- } \\
\text { ter- }\end{array}$ & \multirow{2}{*}{\multicolumn{2}{|c|}{ Average. }} & \multirow{2}{*}{$\begin{array}{c}\mathrm{Ob}- \\
\text { served. }\end{array}$} & \multirow{2}{*}{$\begin{array}{l}\text { Calou- } \\
\text { lated. }\end{array}$} \\
\hline No. 707. & No. 504. & & & & \\
\hline $\begin{array}{l}{ }^{\circ} C . \\
-84.3 \\
-84.7 \\
-85.3 \\
-86.2 \\
-87.2 \\
-89.7 \\
-92.5 \\
-96.0 \\
-100.7 \\
-104.0 \\
-108.3 \\
-114.9 \\
-119.8 \\
-126.1 \\
-134.6 \\
-140.5 \\
-143.1\end{array}$ & $\begin{array}{l}{ }^{\circ} C . \\
-83.7 \\
-84.3 \\
-84.9 \\
-85.7 \\
-86.9 \\
-89.3 \\
-92.1 \\
-95.7 \\
-100.5 \\
-103.9 \\
-108.2 \\
-115.0 \\
-119.9 \\
-126.1 \\
-134.7 \\
-140.6 \\
-143.2\end{array}$ & $\begin{array}{l}{ }^{\circ} C . \\
-84.0 \\
-84.5 \\
-\quad 85.1 \\
-85.9 \\
-87.0 \\
-89.5 \\
-92.3 \\
-95.8 \\
-100.6 \\
-104.0 \\
-108.2 \\
-115.1 \\
-119.9 \\
-126.1 \\
-134.6 \\
-140.6 \\
-143.2\end{array}$ & $\begin{array}{r}{ }^{\circ} A b s . \\
189.1 \\
188.6 \\
188.0 \\
187.2 \\
186.1 \\
183.6 \\
180.8 \\
177.3 \\
172.5 \\
169.1 \\
164.9 \\
158.0 \\
153.2 \\
147.0 \\
138.5 \\
132.5 \\
129.9\end{array}$ & $\begin{array}{c}\text { Mm. } h g . \\
760 \\
730 \\
700 \\
650 \\
600 \\
500 \\
400 \\
300 \\
200 \\
150 \\
100 \\
50 \\
30 \\
15 \\
6 \\
2.5 \\
1\end{array}$ & $\begin{array}{c}M m . h g . \\
760 \\
731 \\
700 \\
658 \\
600 \\
499 \\
400 \\
300 \\
199 \\
147 \\
99 \\
53 \\
30 \\
15 \\
5.2 \\
2.3 \\
1.58\end{array}$ \\
\hline
\end{tabular}

ISOBUTANE.

\begin{tabular}{|r|r|r|r|r|r|}
\hline-13.4 & -13.4 & -13.4 & 259.7 & 760 & 760 \\
-14.8 & -15.0 & -14.9 & 258.2 & 730 & 731 \\
-16.4 & -16.6 & -16.5 & 258.6 & 700 & 694 \\
-19.1 & -19.1 & -19.1 & 254.0 & 650 & 651 \\
-22.0 & -22.1 & -22.0 & 251.1 & 600 & 598 \\
-27.7 & -27.8 & -27.7 & 245.4 & 500 & 500 \\
-34.0 & -34.2 & -34.1 & 239.0 & 400 & 400 \\
-41.1 & -2.3. & -41.1 & 232.0 & 300 & 305 \\
-61.3 & -61.4 & -61.4 & 211.7 & 100 & 115 \\
-72.6 & -72.8 & -72.7 & 200.4 & 50 & 58 \\
-80.8 & -80.9 & -80.9 & 192.2 & 30 & 32 \\
-90.8 & -90.6 & -90.7 & 182.4 & 15 & 15 \\
-98.5 & -98.2 & -98.4 & 174.7 & 7 & 7.4 \\
-106.3 & -106.3 & -106.3 & 166.8 & 3 & 3.5 \\
-114.8 & -114.8 & -114.8 & 158.3 & 1 & 1 \\
\hline
\end{tabular}


TABLE 1.-Vapor pressures at saturation of various compounds at temperatures below the normal boiling point and pressures ranging from 0 to $760 \mathrm{~mm}$.-Continued.

AMMONIA.

\begin{tabular}{|c|c|c|c|c|c|}
\hline \multicolumn{4}{|c|}{ Temperature. } & \multicolumn{2}{|c|}{ Pressure. } \\
\hline By pent & $\begin{array}{l}\text { ane ther- } \\
\text { eter- }\end{array}$ & \multirow{2}{*}{\multicolumn{2}{|c|}{ Average. }} & \multirow{2}{*}{$\begin{array}{c}\text { Ob- } \\
\text { served. }\end{array}$} & \multirow{2}{*}{$\begin{array}{l}\text { Calcu- } \\
\text { lated. }\end{array}$} \\
\hline No. 707. & No. 504. & & & & \\
\hline $\begin{array}{l}{ }^{\circ} C . \\
-34.6 \\
-35.4 \\
-36.3 \\
-37.8 \\
-39.4 \\
-42.5 \\
-46.2 \\
-50.8 \\
-56.9 \\
-60.9 \\
-66.8 \\
-77.0 \\
-82.3 \\
-89.1 \\
-96.9 \\
-101.4 \\
\ldots . . . . .\end{array}$ & $\begin{array}{r}-C . \\
-34.6 \\
-35.4 \\
-36.3 \\
-37.7 \\
-39.3 \\
-42.4 \\
-46.2 \\
-50.6 \\
-56.7 \\
-60.7 \\
-66.5 \\
-2.1 .9 \\
-81.9 \\
-88.7 \\
-96.5 \\
-101.0 \\
-113.3\end{array}$ & $\begin{array}{l}{ }^{\circ} C . \\
-34.6 \\
-35.4 \\
-36.3 \\
-37.7 \\
-39.3 \\
-42.4 \\
-46.3 \\
-50.7 \\
-56.8 \\
-60.8 \\
-66.6 \\
-76.1 \\
-82.1 \\
-88.9 \\
-96.7 \\
-101.2 \\
-113.3\end{array}$ & $\begin{array}{r}A b s . \\
238.5 \\
237.7 \\
236.8 \\
235.4 \\
233.8 \\
230.7 \\
226.8 \\
222.4 \\
216.3 \\
212.3 \\
206.5 \\
197.0 \\
191.0 \\
184.2 \\
176.4 \\
171.9 \\
159.8\end{array}$ & $\begin{array}{r}. M m . h g . \\
760 \\
730 \\
700 \\
650 \\
600 \\
500 \\
400 \\
300 \\
200 \\
150 \\
100 \\
50 \\
30 \\
15 \\
7 \\
4 \\
1\end{array}$ & $\begin{array}{c}M m . h g . \\
760 \\
730 \\
699 \\
648 \\
595 \\
501 \\
400 \\
306 \\
205 \\
154 \\
100 \\
45 \\
26 \\
14 \\
5.4 \\
3.1 \\
.6\end{array}$ \\
\hline
\end{tabular}

PROPANE

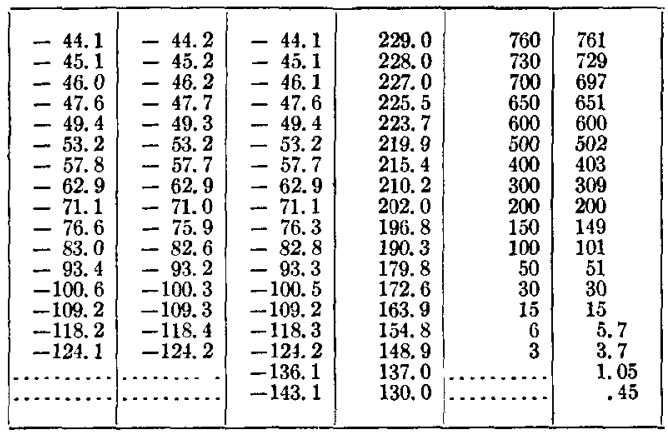

PROPYLENE.

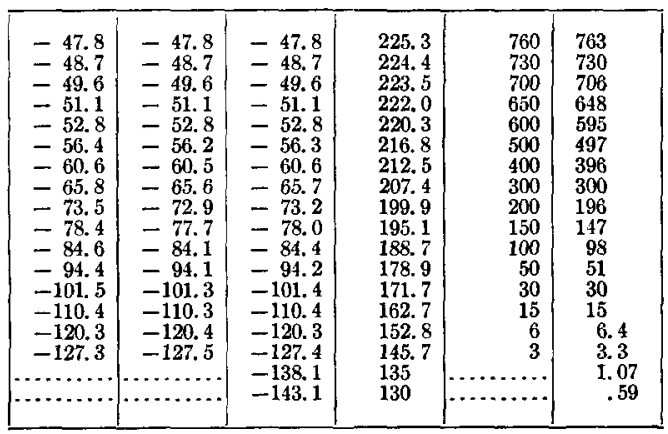


TABLE 1.-Vapor pressures at saturation of various compounds at temperatures below the normal boiling point and pressures ranging from 0 to $760 \mathrm{~mm}$.-Continued.

NORMAL BUTANE.

\begin{tabular}{|c|c|c|c|c|c|c|}
\hline \multicolumn{5}{|c|}{ Temperature. } & \multicolumn{2}{|c|}{ Pressure. } \\
\hline \multicolumn{2}{|c|}{$\begin{array}{l}\text { By pentane ther- } \\
\text { mometer- }\end{array}$} & \multirow{2}{*}{$\begin{array}{c}\text { By } \\
\text { mercury } \\
\text { ther- } \\
\text { mometer. }\end{array}$} & \multirow{2}{*}{\multicolumn{2}{|c|}{ Average. }} & \multirow{2}{*}{$\begin{array}{l}\text { Ob- } \\
\text { served. }\end{array}$} & \multirow{2}{*}{$\begin{array}{l}\text { Calcu- } \\
\text { lated. }\end{array}$} \\
\hline No. 707. & No. 504 . & & & & & \\
\hline $\begin{array}{l}{ }^{\circ} C . \\
-0.3 \\
-1.6 \\
-2.9 \\
-4.9 \\
-7.2 \\
-12.2 \\
-18.2 \\
-25.3 \\
-34.6 \\
-40.4 \\
-47.4 \\
-58.3 \\
-65.5 \\
-76.1 \\
-85.4 \\
-93.3 \\
100.0 \\
\ldots \ldots \ldots\end{array}$ & $\begin{array}{l}{ }^{\circ} C . \\
-0.3 \\
-1.5 \\
-2.8 \\
-5.1 \\
-7.1 \\
-12.3 \\
-18.0 \\
-25.3 \\
-34.7 \\
-40.3 \\
-47.6 \\
-58.2 \\
-65.3 \\
-75.2 \\
-85.1 \\
-93.1 \\
-99.8 \\
\ldots . . . .\end{array}$ & 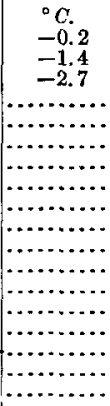 & $\begin{array}{r}\circ C . \\
-0.3 \\
-1.5 \\
-2.8 \\
-5.0 \\
-7.2 \\
-12.3 \\
-18.1 \\
-25.3 \\
-34.6 \\
-40.3 \\
-47.5 \\
-58.3 \\
-65.4 \\
-75.6 \\
-85.3 \\
-93.2 \\
-99.9 \\
-113.1\end{array}$ & $\begin{array}{l}{ }^{\circ} A b s . \\
272.8 \\
271.6 \\
270.3 \\
268.1 \\
265.9 \\
260.8 \\
255.0 \\
247.8 \\
238.5 \\
232.8 \\
225.6 \\
214.8 \\
207.7 \\
197.5 \\
187.8 \\
179.9 \\
173.2 \\
160.0\end{array}$ & $\begin{array}{r}M m . h g . \\
760 \\
730 \\
700 \\
650 \\
600 \\
500 \\
400 \\
300 \\
200 \\
150 \\
100 \\
50 \\
31 \\
15 \\
7 \\
3 \\
1 \\
\ldots \ldots . .\end{array}$ & $\begin{array}{c}M m . h g . \\
760 \\
731 \\
701 \\
652 \\
604 \\
504 \\
404 \\
300 \\
196 \\
148 \\
100 \\
52 \\
32 \\
15 \\
7 \\
3 \\
1 \\
.31\end{array}$ \\
\hline
\end{tabular}

SULPHUR DIOXIDE.

\begin{tabular}{|c|c|c|c|c|c|}
\hline \multicolumn{4}{|c|}{ Temperature. } & \multicolumn{2}{|c|}{ Pressure. } \\
\hline \multicolumn{2}{|c|}{$\begin{array}{l}\text { By pentane ther- } \\
\text { mometer- }\end{array}$} & \multirow{2}{*}{\multicolumn{2}{|c|}{ Average. }} & \multirow{2}{*}{$\begin{array}{l}\text { Ob- } \\
\text { served. }\end{array}$} & \multirow{2}{*}{$\begin{array}{l}\text { Calcu- } \\
\text { lated. }\end{array}$} \\
\hline No. 707. & No. 504. & & & & \\
\hline $\begin{array}{c}{ }^{\circ} C . \\
-11.1 \\
-12.0 \\
-13.1 \\
-14.8 \\
-16.5 \\
-20.4 \\
-24.8 \\
-30.5 \\
-37.8 \\
-42.3 \\
-48.4 \\
-57.6 \\
-64.5 \\
a-73.0 \\
-76.1 \\
-81.5 \\
-87.5 \\
-94.5\end{array}$ & $\begin{array}{l}{ }^{\circ} C . \\
-10.9 \\
-11.8 \\
-12.9 \\
-14.6 \\
-16.3 \\
-20.3 \\
-24.9 \\
-30.4 \\
-37.7 \\
-42.2 \\
-48.3 \\
-57.4 \\
-64.6 \\
a-72.7 \\
-76.0 \\
-81.2 \\
-87.2 \\
-94.2\end{array}$ & $\begin{array}{l}{ }^{\circ} C . \\
-11.0 \\
-11.9 \\
-13.0 \\
-14.7 \\
-18.4 \\
-20.3 \\
-24.8 \\
-30.4 \\
-37.8 \\
-42.3 \\
-48.3 \\
-57.5 \\
-64.5 \\
a-72.9 \\
-76.0 \\
-81.3 \\
-87.4 \\
-94.4\end{array}$ & $\begin{array}{r}{ }^{\circ} A b s . \\
262.1 \\
261.2 \\
260.1 \\
258.4 \\
256.7 \\
252.8 \\
248.3 \\
242.7 \\
235.3 \\
230.8 \\
224.8 \\
215.6 \\
208.6 \\
a 200.2 \\
197.1 \\
191.8 . \\
185.7 \\
178.7\end{array}$ & $\begin{array}{c}M m . h g . \\
760 \\
730 \\
700 \\
650 \\
600 \\
500 \\
400 \\
300 \\
200 \\
150 \\
100 \\
50 \\
30 \\
16 \\
12 \\
7 \\
3 \\
.5\end{array}$ & $\begin{array}{c}M m . h g . \\
760 \\
735 \\
697 \\
647 \\
599 \\
499 \\
400 \\
292 \\
196 \\
149 \\
101 \\
52 \\
30 \\
15 \\
11 \\
6.5 \\
3.4 \\
.2\end{array}$ \\
\hline
\end{tabular}

NITROUS OXIDE.

\begin{tabular}{|r|r|r|r|r|r|}
\hline-88.7 & -88.6 & -88.7 & 184.4 & 760 & $\ldots \ldots \ldots$. \\
-89.3 & -89.2 & -89.3 & 183.8 & 730 & $\ldots \ldots \ldots \ldots$ \\
$-\mathbf{- 9 0 . 1}$ & -90.0 & -90.1 & 183.0 & 700 & $\ldots \ldots \ldots$. \\
-90.6 & $a-90.5$ & $a-90.6$ & $a 182.5$ & 666 & 666 \\
-91.0 & -91.0 & -91.0 & 182.1 & 650 & 646 \\
-93.0 & -91.8 & -91.9 & 181.2 & 600 & 600 \\
-96.5 & -93.9 & -93.9 & 179.2 & 500 & 500 \\
-99.6 & -96.4 & -96.4 & 176.7 & 400 & 399 \\
-103.7 & -103.6 & -99.5 & 173.6 & 300 & 300 \\
-106.7 & -106.6 & -103.7 & 169.4 & 200 & 200 \\
-110.8 & -110.7 & -110.8 & 166.4 & 150 & 149 \\
-117.3 & -117.2 & -117.2 & 162.3 & 100 & 97 \\
-121.1 & -121.1 & -121.1 & 155.9 & 50 & 48 \\
-126.8 & -127.1 & -127.0 & 146.1 & 30 & 30 \\
-131.2 & -131.4 & -131.3 & 141.8 & 15 & 14.3 \\
-138.9 & -138.8 & -138.9 & 134.2 & 7 & 8.0 \\
-144.2 & -144.0 & -144.1 & 129.0 & 1 & 1.2 \\
\hline
\end{tabular}

a Alove this temperature the nitrous oxide was liquid, below this temperature it was solid. 


\section{CALCULATION OF THE VAPOR-PRESSURE CURVES.}

Vapor-pressure curves were calculated from the results given in Table 1 with the aid of the empirical and approximate formula of Nernst: ${ }^{a}$

$$
\log P=\frac{\lambda_{0}}{4.571 T}=1.75 \log T-\frac{\epsilon}{4.571} T+\mathrm{C}
$$

in which $P$ is the vapor pressure, $T$ is the absolute temperature, and $\lambda, \epsilon$, and $\mathrm{C}$ are oonstants. The constants $\lambda, \epsilon$, and $\mathrm{C}$ may be found by taking values of $P$ at three different temperatures. The table following shows the values of $P$ and $T$ that were taken in the oase of each cqmpound:

Values of $P$ and $T$ for various compounds.

\begin{tabular}{|c|c|c|c|c|c|}
\hline Compound. & $P$. & $T$. & Compound. & $P$. & $T$ \\
\hline 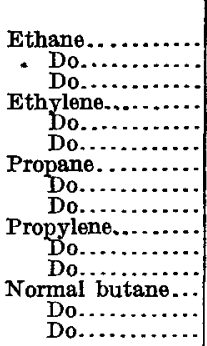 & $\begin{array}{r}\text { Mm. hg. } \\
760 \\
200 \\
4 \\
700 \\
300 \\
17 \\
600 \\
200 \\
15 \\
730 \\
300 \\
15 \\
760 \\
300 \\
15\end{array}$ & $\begin{array}{l}{ }^{\circ} A b s . \\
183.8 \\
161.8 \\
123.6 \\
167.7 \\
154.9 \\
123.7 \\
223.7 \\
202.0 \\
163.9 \\
224.4 \\
207.4 \\
162.7 \\
272.8 \\
247.8 \\
197.5\end{array}$ & 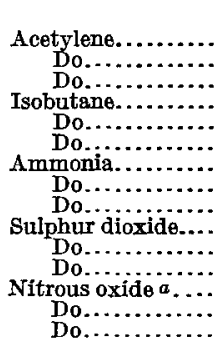 & $\begin{array}{r}M m . h g . \\
760 \\
300 \\
15 \\
760 \\
500 \\
15 \\
760 \\
400 \\
100 \\
760 \\
400 \\
30 \\
666 \\
300 \\
30\end{array}$ & $\begin{array}{l}{ }^{\circ} A b s . \\
189.1 \\
177.3 \\
147.0 \\
259.7 \\
245.4 \\
182.4 \\
238.5 \\
226.8 \\
200.5 \\
262.1 \\
248.3 \\
208.6 \\
182.5 \\
173.6 \\
152.0\end{array}$ \\
\hline
\end{tabular}

a Above $182.5^{\circ}$ the nitrous oxide was liquid and below this temperature it was solid. Only the solid phase was considered in calculating pressures.

The equations of the curves shown in figures 3 to 7 for the different gases are as follows:
(Ethane)
$\log P=\frac{-1050.8}{T}+1.75 \log T-0.0134 T+7.102$.
(Ethylene)
$\log P=\frac{-762.5}{T}+1.75 \log T-0.0053 T+4.391$.
(Propane)
$\log P=\frac{-863.6}{T}+1.75 \log T-0.0007 T+2.683$.
(Propylene)
$\log P=\frac{-709.6}{T}+1.75 \log T+0.0039 T+1.025$.
(Normal butane) $\quad \log P=\frac{-1633.3}{T}+1.75 \log T-0.0109 T+7.589$.
(Acetylene) $\quad \log P=\frac{-957.2}{T}+1.75 \log T-0.0015 T+3.672$. 
(Isobutane)

$\log P=\frac{-1632.6}{T}+1.75 \log T-0.0158 T+9.068$.

(Ammonia)

$$
\log P=\frac{-1951.7}{T}+1.75 \log T-0.0155 T+10.606
$$

(Sulphur dioxide) $\log P=\frac{-1951.4}{T}+1.75 \log T-0.0127 T+9.440$.

(Nitrous oxide) $\quad \log P=\frac{-1096.7}{T}+17.5 \log T+.0005 T+4.866$.

The results may also be expressed by plotting the common logarithm of the pressure $\left(\log _{\mathrm{o}} P\right)$ against the reciprocal of the absolute temperature $T$. The straight-line curves in figures 7 to 10 were drawn by obtaining an equation from the average of all the results computed by the method of least squares and drawing the lines according to these equations. The equations for the curves are as follows:

$\begin{array}{ll}\text { (Ethylene) } & \log _{0} P=-\frac{767.8}{T}+7.433 . \\ \text { (Ethane) } & \log _{0} P=-\frac{831.4}{T}+7.42 . \\ \text { (Ammonia) } & \log _{0} P=-\frac{1371.86}{T}+8.64 . \\ \text { (Acetylene) } & \log _{\circ} P=-\frac{1127.09}{T}+8.84 . \\ \text { (Isobutane) } & \log _{\circ} P=-\frac{1056.25}{T}+6.98 .\end{array}$

(Sulphur dioxide) $\log _{\mathfrak{c}} P=-\frac{1448.01}{T}+8.425$.

(Nitrous oxide) $\quad \log _{c} P=-\frac{1232.2}{T}+9.579$.

(Propane) $\quad \log _{\mathfrak{o}} P=-\frac{983.7}{T}+7.173$.

(Propylene) $\quad \log _{\mathrm{o}} P=-\frac{1006.1}{T}+7.340$.

(Normal butane) $\log _{0} P=-\frac{1224.5}{T}+7.394$.

\section{HEAT OF EVAPORATION OF ETHANE AND ETHYLENE.}

The heat of evaporation of ethane and that of ethylene may be calculated from the Clausius-Clapeyron equation:

$$
\mathrm{Q}=\frac{\left(d \log _{\mathrm{n}} P\right)}{d T} \mathrm{R} T^{2}
$$

in which $\mathrm{Q}$ is the heat of evaporation in calories per gram-molecule, $\log _{n} P$ is the natural logarithm of the vapor pressure, $T$ the absolute temperature, and $\mathrm{R}$ the gas constant (1.985). 


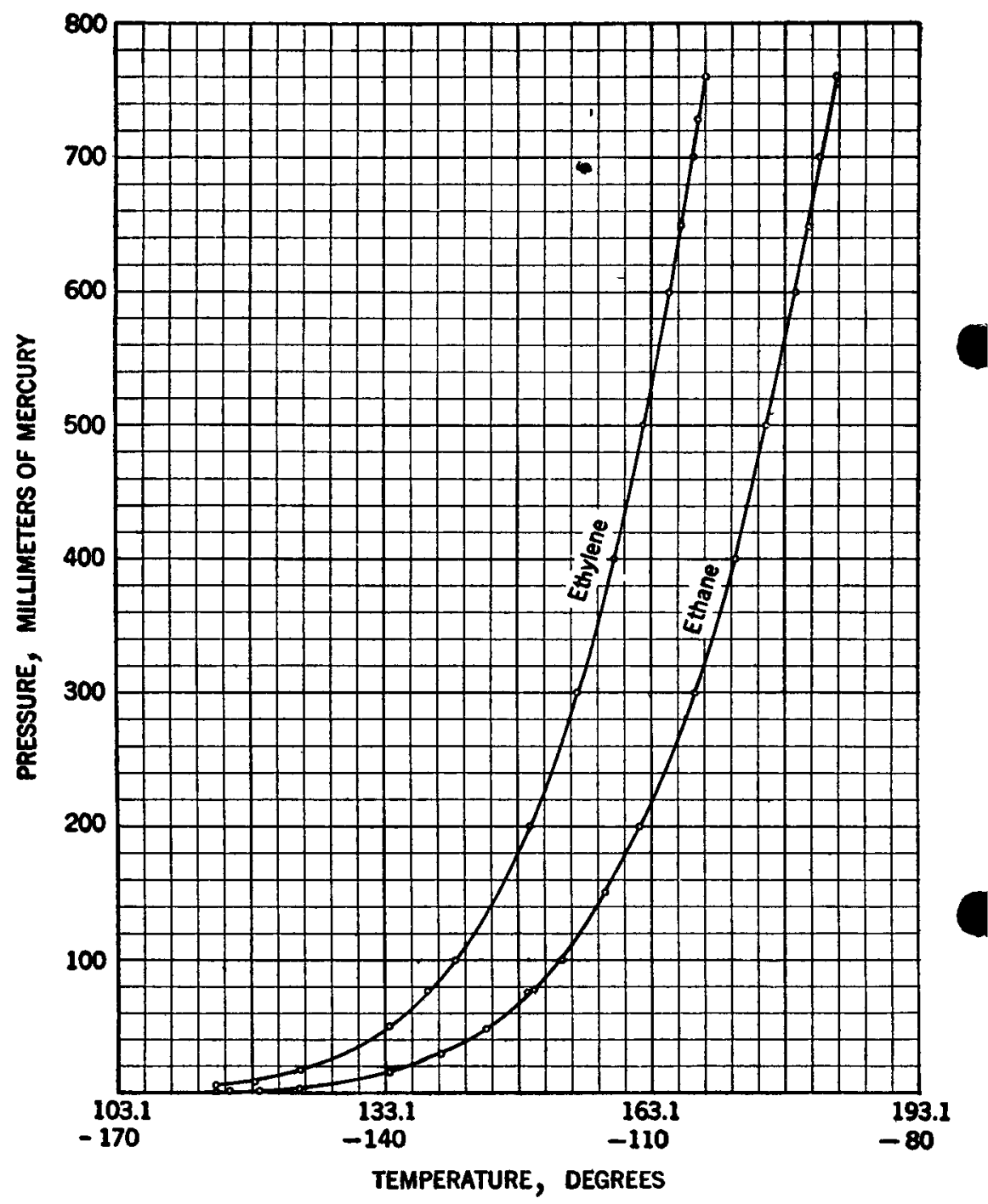

(Upper line, absolute scale; lower line, centigrade scale)

FIGURE 3-Vapor-pressure curves for ethylene and ethane, showing pressure plotted as a function of the temperature. 


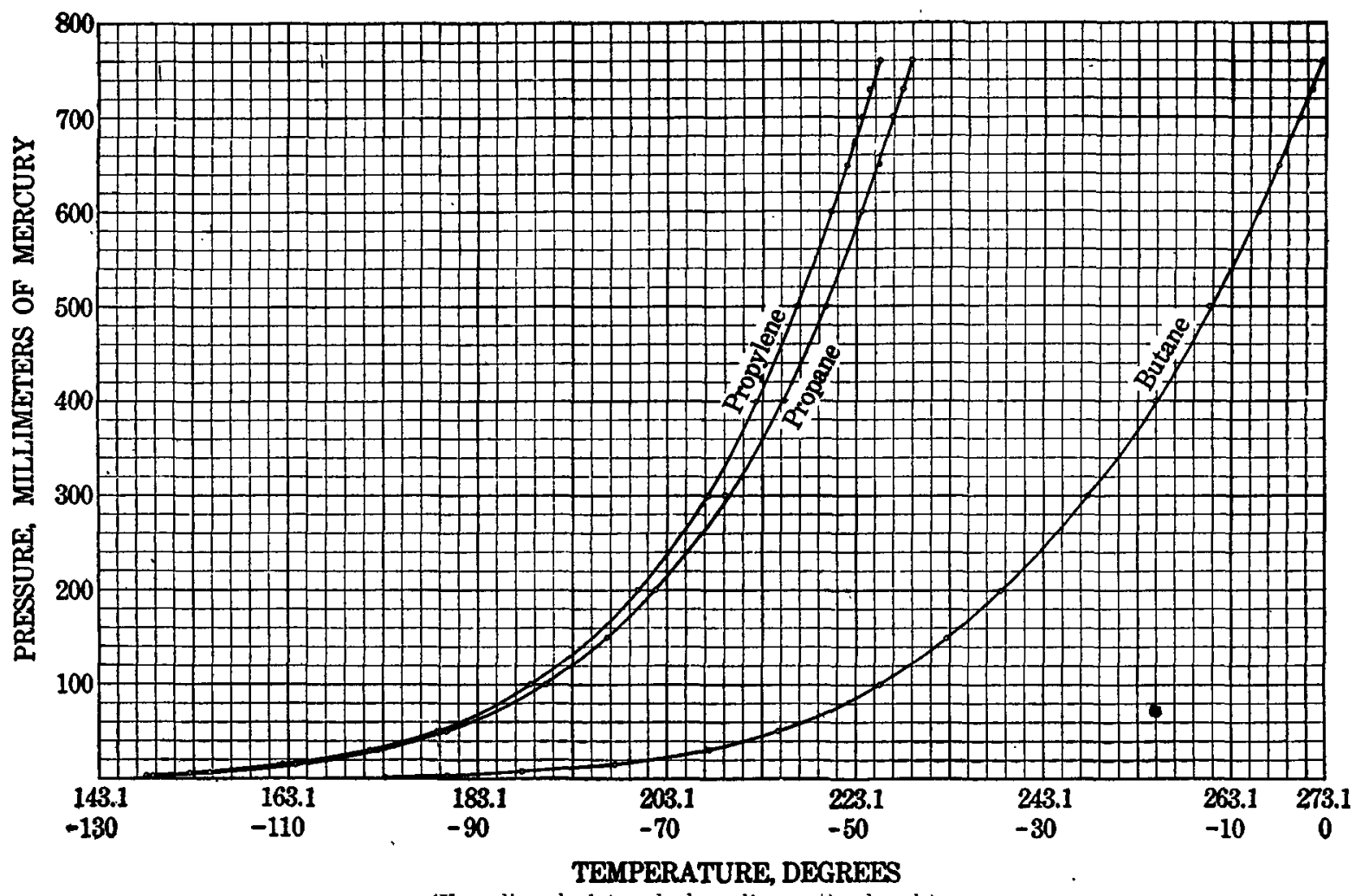




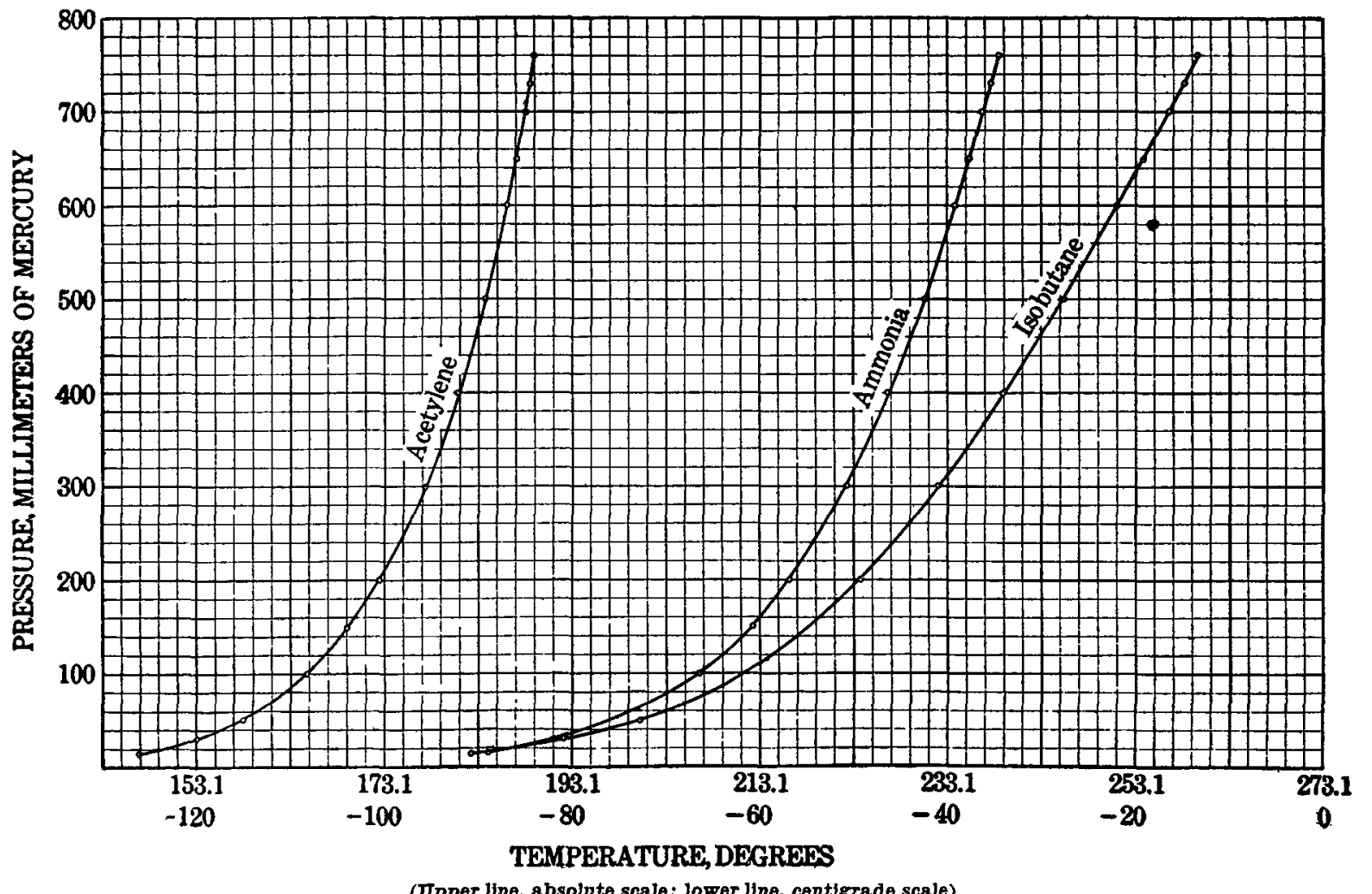




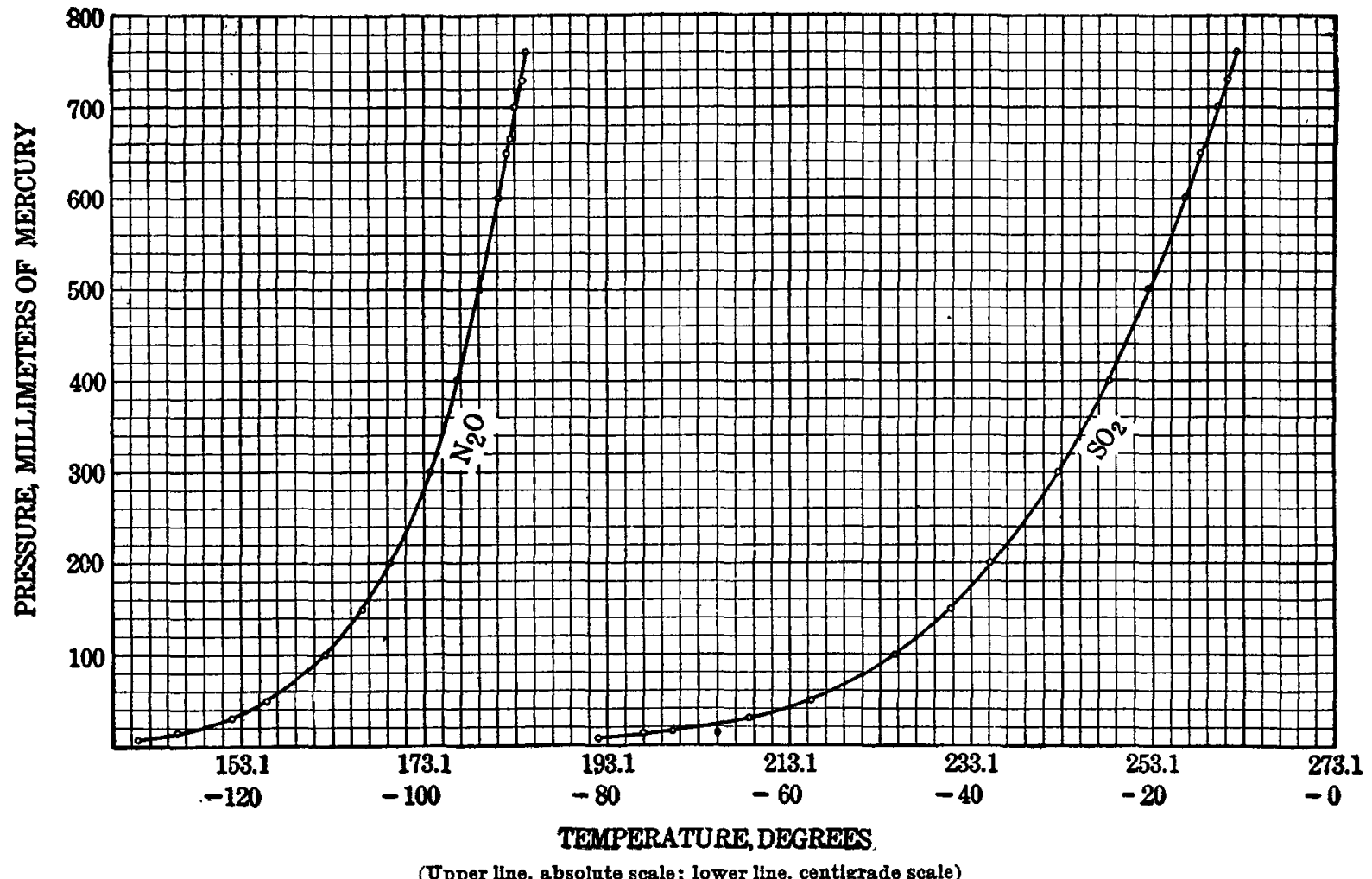

(Upper line, absolute scale; lower line, centigrade scale)

FIGURE 6.-Vapor-pressure curves for nitrous oxide and sulphur dioxide, showing pressure plotted as a function of the temperature. 


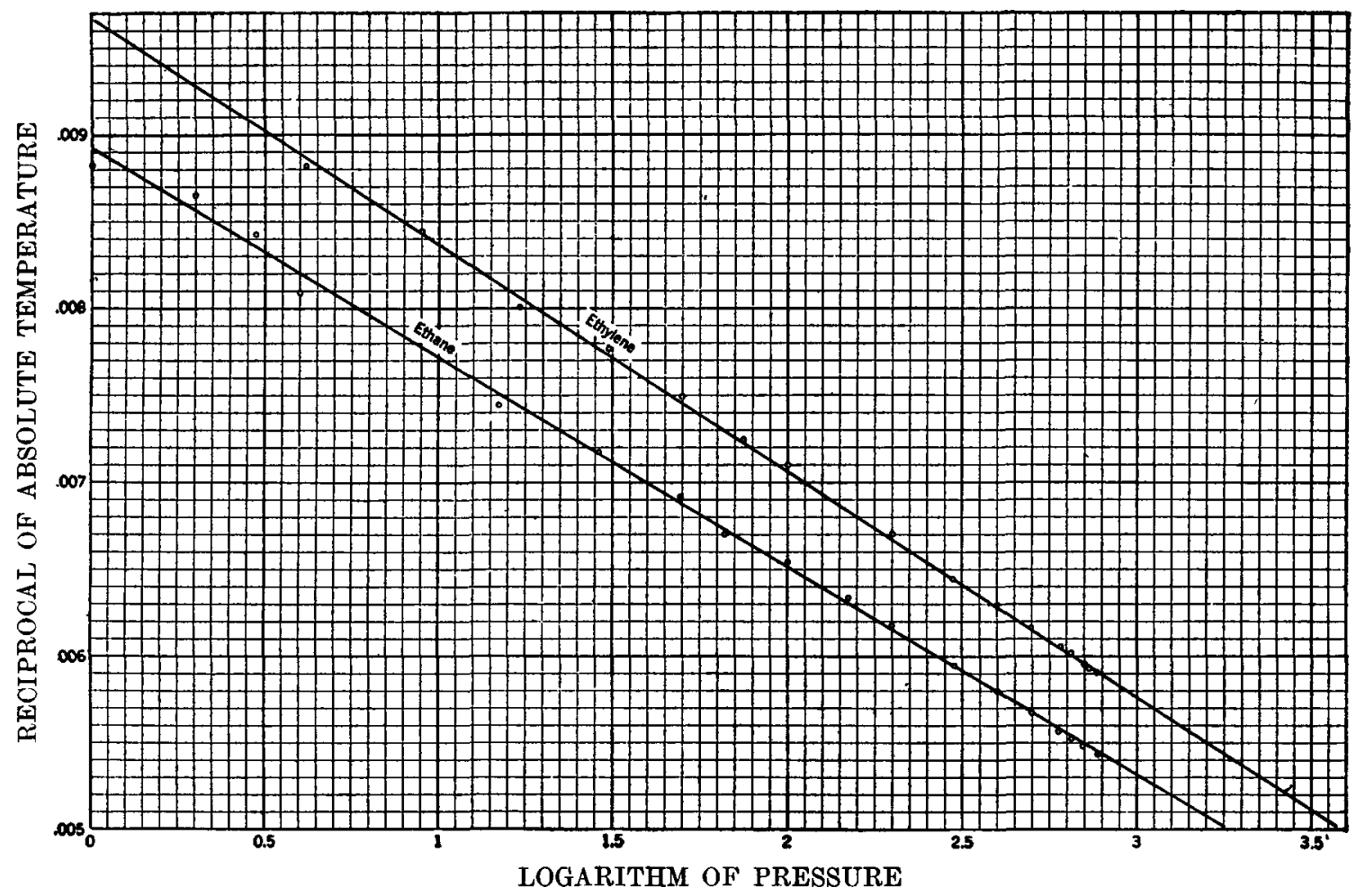

Fig URE 7.-Vapor-pressure curves for ethylene and ethane, showing common logarithm of pressure plotted as a function of the reciprocal of the absolute temperature. 


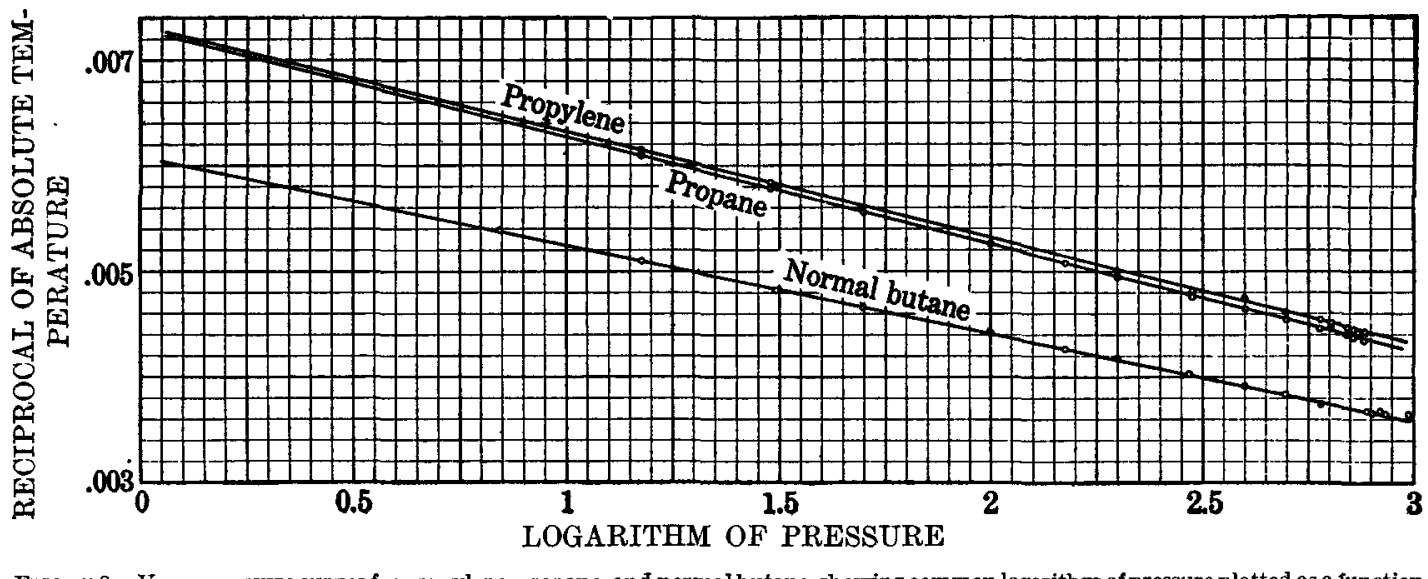

FIGURE 8.-Vapor-pressure curves for propylene, propane, and normal butane, showing common logarithm of pressure plotted as a function of the reciprocal of the absolute temperature. 


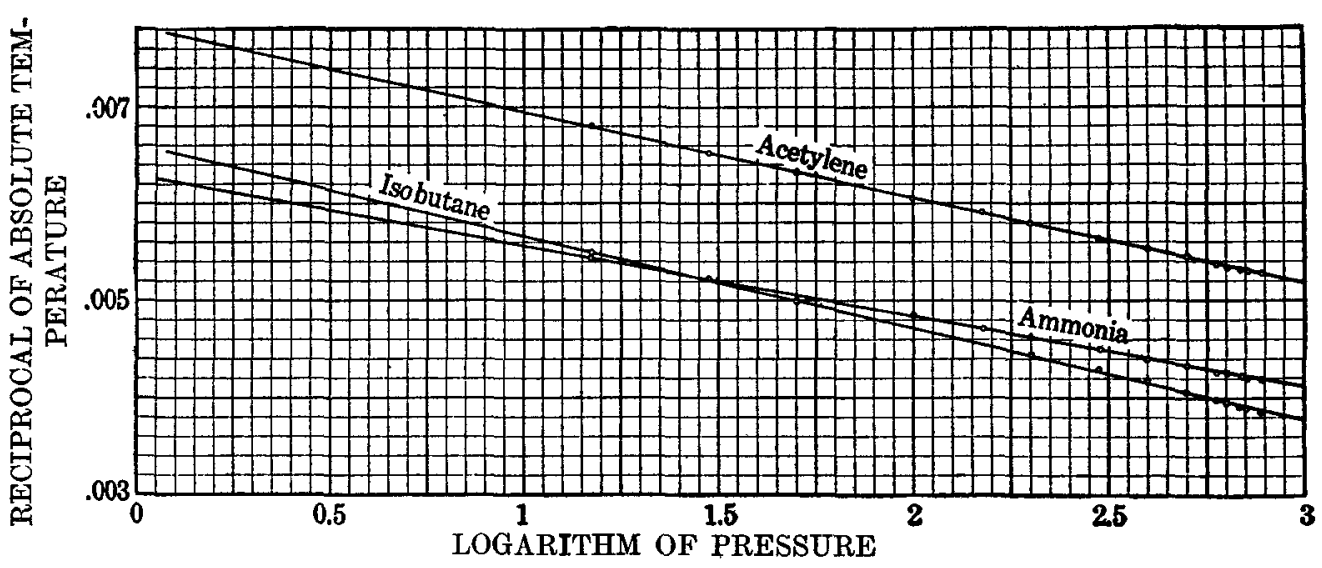

Figure 9.-Vapor-pressure curves for acetylene, ammonia, and isobutane, showing common logarithm of pressure plotted as a function of the reciprocal of the absolute temperature. 
Integrating equation 1 and assuming that $Q$ is a constant, which is permissible, however, only for a limited temperature range, one obtains:

$$
\log _{\mathrm{n}} P=-\frac{\mathrm{Q}}{\mathrm{R} T}+\text { constant }
$$

The values $767.8,831.4$, etc., in the equations for the straight-line curves in figures 3 to 6 each represent the average of all the determined points on the curve. By substituting these values in equa-

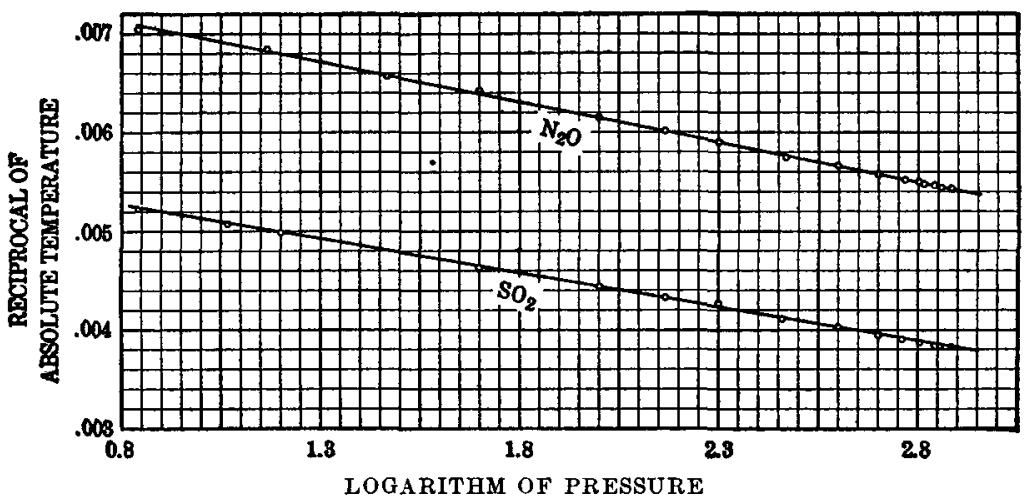

FIGURE 10.-Vapor-pressure curves for nitrous oxide and sulphur dioxide, showing common logarithm of pressure plotted as a function of the reciprocal of the absolute temperature.

tion 2 and changing from common to natural logarithms, the average values for $\mathrm{Q}$, over the temperature range studied, are as follows:
(Ethylene)
(Ethane)
(Ammonia)
(Acetylene)
(Isobutane)
$\mathrm{Q}=831.4 \times 4.571=3,800$ calories.
$\mathrm{Q}=1,371.86 \times 4.571=6,271$ calories.
$\mathrm{Q}=1,127.09 \times 4.571=5,152$ calories.
$\mathrm{Q}=1,056.25 \times 4.571=4,828$ calories.
$\mathrm{Q}=767.8 \times 4.571=3,510$ calories.
(Sulphur dioxide) $\mathrm{Q}=1,448.01 \times 4.571=6,619$ calories.
(Nitrous oxide) $Q=1,232.2 \times 4.571=5,626$ calories.
_. (Propane) $Q=983.7 \times 4.571=4,496$ calories.
(Propylene) $\quad \mathrm{Q}=1,006.1 \times 4.571=4,599$ calories.
(Normal butane) $Q=1,224.5 \times 4.571=5,597$ calories.

These heats of evaporation are only approximately correct. Q may be varied considerably, and yet the calculated vapor pressures may fall well within the limits of error of experimentation.

\section{VAPOR-PRESSURE MEASUREMENTS COMPARED WITH THOSE OBTAINED BY OTHER INVESTIGATIONS.}

The only vapor-pressure values at low temperatures that have been determined for ethane or ethylene, aside from their vapor pressures at their normal boiling points, are those of Maas and McIntosh, ${ }^{a}$ who

a Maas, O., and McIntosh, D., The physical properties of ethane, ethylene, and acetylene: Jour. Am. Chem. Soc., vol. 36, 1914, p. 737. 
worked out values for ethane from $-88.5^{\circ} \mathrm{C}$. (the normal boiling point found by them) to $-107.8^{\circ} \mathrm{C}$. At $-107.8^{\circ} \mathrm{C}$. they found that the vapor pressure was $287 \mathrm{~mm}$., or the temperature differed $2.3^{\circ}$ from that found by the authors at the same pressure, $287 \mathrm{~mm}$.

The normal boiling point of ethylene has been found by Olszewski ${ }^{a}$ and by Ramsey and Travers ${ }^{b}$ to be $170.5^{\circ}$ on the absolute scale. Travers believes both of these values to be about $1^{\circ}$ too low and places greater faith in the value $169.5^{\circ}$ absolute found by Wroblewski and Witkowski. ${ }^{c}$ The authors of this paper found the boiling point to be $169.2^{\circ}$ absolute.

\section{NITROUS OXIDE.}

Vapor pressures at saturation below the normal boiling point have not been determined for nitrous oxide by other investigators. For the normal boiling point, Faraday ${ }^{d}$ found $-87.2^{\circ} \mathrm{C}$., Caillet ${ }^{e}$ found $-92^{\circ} \mathrm{C}$., and Ramsey and Shields $f$ found $-89.8^{\circ} \mathrm{C}$. The agreement between these results is not good. The value as determined by the writers is $-88.7^{\circ} \mathrm{C}$.

\section{SULPHUR DIOXIDE.}

Vapor pressures at saturation for sulphur dioxide have been determined by Regnault $g$ for temperatures ranging from $-30^{\circ} \mathrm{C}$. to $65^{\circ} \mathrm{C}$. and by Pictet ${ }^{h}$ for those ranging from $-30^{\circ} \mathrm{C}$. to $50^{\circ} \mathrm{C}$. The values obtained by them and those found by the authors of this paper are as follows:

Vapor pressures of sulphur dioxide at temperatures of $-10^{\circ}$ to $-30^{\circ} \mathrm{C}$.

\begin{tabular}{|c|c|c|c|}
\hline \multirow[b]{2}{*}{$\begin{array}{l}\text { Tempera- } \\
\text { ture. }\end{array}$} & \multicolumn{3}{|c|}{ Pressure as determined by- } \\
\hline & Regnault. & Pictet. & $\begin{array}{c}\text { Burrell } \\
\text { and } \\
\text { Robertson. }\end{array}$ \\
\hline $\begin{array}{r}{ }^{\circ} \mathrm{C} . \\
-10 . .\end{array}$ & $\begin{array}{r}M m . h g \\
760\end{array}$ & $\begin{array}{r}M m \cdot h g . \\
760\end{array}$ & $\begin{array}{c}M m . h g . \\
\cdots \cdots\end{array}$ \\
\hline $\begin{array}{l}-15 \ldots \\
-20 \ldots \\
-25 \ldots \\
-30 \ldots\end{array}$ & $\begin{array}{l}608 \\
479 \\
372 \\
296\end{array}$ & $\begin{array}{l}578 \\
464 \\
418 \\
274\end{array}$ & $\begin{array}{l}640 \\
508 \\
398 \\
306\end{array}$ \\
\hline
\end{tabular}

The results by Regnault and by Pictet when plotted do not make a smooth curve, some of the points being from $1^{\circ}$ to $3^{\circ}$ off the curve.

a Travers, M. W., Experimental study of geses, 1901, p. 243.

b Travers, M. W., Loc. cit.

c Travers, M. W., Loc. cit.

d Philos. Trans. Roy Soc. London, vol. 135, ser. 1, 1845, p. 155; cited by Landolt and Börnstein, Physikalisch-ch6mische Tabellen, 1912, p. 381.

e Arch. de Genève, vol. 66, 1ör 8 , p. 16; cited by Landolt and Börnstein, Physikalisch-chemische Tabellen, 1912 , p. 381 .

f Jour. Chem. Soc., vol. 63, 1893, p. 833; cited by Landolt and Börnstein, Physikalisch-chemische Tabellen, 1912, p. 381.

o Mem. de l'Acad., vol. 26, 1862, p. 535; cited by Landolt and Börnstein, Physikalisch-chemische TabelIen, 1912, p. 381.

$h$ Arch. de Genève, vol. 13, 1885, p. 212; cited by Landolt and Börnstein, Physikalisch-chemische'Tabellen, 1912, p. 381. 
AMMONIA.

Brill ${ }^{a}$ has determined vapor pressures at saturation for ammonia between $-80.0^{\circ}$ and $-33.0^{\circ} \mathrm{C}$. His results are shown in the following table along with those of the authors of this paper. The latter were taken from a curve similar to the one shown in figure 5, but drawn to much larger scale than shown in the figure.

Vapor pressures of ammonia at temperatures of $-33^{\circ}$ to $-80^{\circ} \mathrm{C}$.

\begin{tabular}{|c|c|c|c|c|c|}
\hline \multirow{2}{*}{$\begin{array}{l}\text { Tempera- } \\
\text { ture. }\end{array}$} & \multicolumn{2}{|c|}{$\begin{array}{c}\text { Pressure as determined } \\
\text { by }-\end{array}$} & \multirow{2}{*}{$\begin{array}{c}\text { Tempera- } \\
\text { ture. }\end{array}$} & \multicolumn{2}{|c|}{$\begin{array}{c}\text { Pressure as determined } \\
\text { by- }\end{array}$} \\
\hline & Brill. & $\begin{array}{c}\text { Burrell } \\
\text { and } \\
\text { Robertson. }\end{array}$ & & Brill. & $\begin{array}{c}\text { Burrell } \\
\text { and } \\
\text { Robertson. }\end{array}$ \\
\hline $\begin{aligned} & C . \\
&- 80.0 \ldots \ldots \\
&-79.0 \ldots \\
&-77.6 \ldots \\
&-75.1 \ldots \\
&-72.7 \ldots \ldots \\
&-70.4 \ldots \ldots \\
&-68.3 \ldots \ldots \\
&-64.4 \ldots \\
&-62.8 \ldots \\
&-60.8 \ldots\end{aligned}$ & $\begin{array}{r}M m . h g . \\
35.2 \\
38.0 \\
44.1 \\
51.8 \\
62.5 \\
74.9 \\
87.5 \\
116.0 \\
136.0 \\
157.6\end{array}$ & $\begin{array}{r}\text { Mm. hg. } \\
37 \\
40 \\
45 \\
53 \\
65 \\
76 \\
88 \\
117 \\
132 \\
151\end{array}$ & $\begin{aligned} & 0 \\
&-59.5 \\
&-56.5 \\
&-56.5 \\
&-54.4 \ldots \\
&-50.7 \ldots \ldots \\
&-46.2 \ldots \ldots \\
&-45.0 \ldots \ldots \\
&-41.5 \ldots \ldots \\
&-39.8 \ldots \\
&-38.2 \ldots \\
&-33.0 . \ldots\end{aligned}$ & $\begin{array}{r}M m . h g . \\
172.4 \\
210.0 \\
239.5 \\
309.3 \\
403.5 \\
437.1 \\
521.9 \\
568.2 \\
610.4 \\
761.0\end{array}$ & $\begin{array}{r}M m . h g . \\
166 \\
209 \\
239 \\
305 \\
400 \\
130 \\
\mathbf{5 2 0} \\
\mathbf{5 8 0} \\
\mathbf{6 3 0}\end{array}$ \\
\hline
\end{tabular}

Brill's pressure measurements were performed by the static method. He measured the temperatures with an iron-constantan thermocouple checked against a calibrated pentane thermometer. The agreement between his work and that of the authors is fairly good, except at temperatures near the normal boiling point. His value, $33.0^{\circ} \mathrm{C}$., is $1.6^{\circ}$ higher than that of the authors. One possible error in his work may be the value he took for the melting point of chloroform. As a check on the accuracy of his temperature measurements he calibrated his thermometer against the melting point of pure chloroform, assuming this to be $63.1^{\circ} \mathrm{C}$., whereas recent measurements by Henning ${ }^{b}$ place it at $63.7^{\circ} \mathrm{C}$.

Brill's work on ammonia is the only work on vapor pressures of gases at low temperatures that covers an extensive range for a substance that the authors also have worked with. Their observations covered a temperature range 20 degrees lower than those of Brill.

\section{APPLICATION OF RESULTS TO SEPARATION OF GASEOUS MUXTURES.}

In Technical Paper $104^{c}$ there were described experiments on the separation of complex gas mixtures by fractional distillation at low temperatures and pressures. The method of separating the paraffin

a J3rill, Otto, [Vapor pressures of liquid ammonia]: Ann. der Physik, vol. 21, 1906, p. 170.

$b$ Henning, F., Die Fixierung der Temperaturskala zwischen 0 und $-193^{\circ}$ [The fixation of the temperature scale between $0^{\circ}$ and $-193^{\circ}$ C.]: Ann. der Physik, Bd. 43, 1913, p. 294.

$c$ Burrell, G. A., Seibert, F. M., Robertson, I. W., Analyses of natural gas and illuminating gas by fractional distillation at low temperatures and pressures: Tech. Paper 104, Bureau of Mines, 1915, 40 pp. 
- hydrocarbons in natural gas and of separating the so-called illuminants (mixtures of saturated, unsaturated, and aromatio hydrocarbons) in carbureted mixed coal and water gas, were described. Regarding a mixture of gases such as methane, ethane, propane, and butane, methane can be removed at the temperature of liquid air, and the ethane separated from the propane, butane, etc., at temperatures ranging from $-150^{\circ} \mathrm{C}$. to $-140^{\circ} \mathrm{C}$. The propane is separated from the higher $p c_{\perp}$ affins at temperatures ranging from $-135^{\circ}$ to $-120^{\circ} \mathrm{C}$.

A method of separating the illuminants in coal gas was also described. The methane, hydrogen, carbon monoxide, nitrogen, and oxygen are removed at the temperature of liquid air, the ethane and ethylene are removed at a temperature not higher than $-140^{\circ} \mathrm{C}$.; the propane and propylene are removed at a temperature not higher than $-120^{\circ} \mathrm{C}$., the butylene, butane, and benzene being left as a residue. The benzene can be separated from the butane and butylene at a temperature of $-78^{\circ} \mathrm{C}$. Benzene can be simply and quickly determined in coal gas by removing the carbon dioxide and water vapor, cooling the mixture at a temperature of $-78^{\circ} \mathrm{C}$., withdrawing the other gases at this temperature, and finally, after the refrigerant has been removed and the benzene vaporized, reading the vapor pressure on a mercury manometer.

The question of separating gas mixtures at low temperatures resolves itself into making the separations at temperatures where the vapor pressures of the two gases to be separated are widely different. Take the case of ethane and propane. At $-89.3^{\circ} \mathrm{C}$, the normal boiling point of ethane, the saturated vapor pressure of ethane is $760 \mathrm{~mm}$., whereas that of propane at $-89.3^{\circ} \mathrm{C}$. is only about $68 \mathrm{~mm}$., the ratio between the two pressures being about 11 to 1 . Separation could, of course, be effected at that temperature, but a much faster separation can be made at a temperature of about $-140^{\circ} \mathrm{C}$. At this temperature the saturated vapor pressure of ethane is about $18 \mathrm{~mm}$. and of propane about $0.5 \mathrm{~mm}$., the ratio being about 36 to 1 .

Recently the authors of this publication had occasion to make an analysis of dentist's laughing gas, which was a mixture of nitrous oxide $\left(\mathrm{N}_{2} \mathrm{O}\right)$ with small amounts of air and water vapor. The mixture was first subjected to a temperature of $-78^{\circ} \mathrm{C}$. and the nitrous oxide and air withdrawn from the mixture, leaving the water vapor behind. Next the air was separated from the nitrous oxide at the temperature of liquid air. Chloroform in air, benzol vapor in air, and gasoline vapor in air have all been easily determined by the authors by fractional distillation at low temperatures. There are many gas mixtures that offer considerable difficulty by other methods of gas analysis that are easily analyzed by this method. 


\section{PUBLICATIONS ON PETROLEUM TECHNOLOGY.}

A limited supply of the following publications of the Bureau of Mines is temporarily available for free distribution: Requests for all publications can not be granted, and to insure equitable distribution applicants are requested to limit their selection to publications that may be of especial interest to them. Requests for publications should be addressed to the Director, Bureau of Mines.

BuLLETIN 88. The condensation of gasoline from natural gas, by G. A. Burrell, F. M. Seibert, and G. G. Oberfell. 1915. 106 pp., 6 pls., 18 figs.

Technical Paper 3. Specifications for the purchase of fuel oil for the Government, ith directions for sampling oil and natural gas, by I. C. Allen. $1911.13 \mathrm{pp}$.

Technical Paper 10. Liquefied products from natural gas, their properties and uses, by I. C. Allen and G. A. Burrell. 1912. 23 pp.

Techical Paper 25. Methods for the determination of water in petroleum and its products, by I. C. Allen and W. A. Jacobs. 1912. 13 pp., 2 figs.

Technical Paper 32. The cementing process of excluding water from oil wells, as practiced in California, by Ralph Arnold and V. R. Garfias. 1913. 12 pp., 1 fig.

Technical Paper 37. Heavy oil as fuel for internal-combustion engines, by I. C. Allen. 1913. $36 \mathrm{pp}$.

Technical Paper 38. Wastes in the production and utilization of natural gas and means for their prevention, by Ralph Arnold and F. G. Clapp. 1913.29 pp.

Technical Paper 42. The prevention of waste of oil and gas from flowing wells in California, with a discussion of special methods used by J. A. Pollard, by Ralph Arnold and V. R. Garfias. 1913.15 pp., 2 pls., 4 figs.

Technical Paper 45. Waste of oil and gas in the Mid-Continent fields, by R. S. Blatchley. 1914. 54 pp., 2 pls., 15 figs.

Technical Paper 49. The flash point of oils; methods and apparatus for its determination, by I. C. Allen and A. S. Crossfield. 1913. 31 pp., 2 figs.

Technigal Paper 57. A preliminary report on the utilization of oil and natural os in Wyoming, by W. R. Calvert, with a discussion of the suitability of natural gas ror making gasoline, by G. A. Burrell. 1913. 23 pp.

Technical Paper 66. Mud-laden fluid applied to well drilling, by J. A. Pollard and A. G. Heggem. 1914. 21 pp., 12 figs.

Technical Paper 68. Drilling wells in Oklahoma by the mud-laden fluid method, by A. G. Heggem and J. A. Pollard. 1914. 27 pp., 5 figs.

Technical Paper 70. Methods of oil recovery as practiced in California, by Ralph Arnold and V. R. Garfias. 1914. 57 pp., 7 figs.

Technical Paper 72. Problems of the petroleum industry; results of conferences at Pittsburgh, Pa., August 1 and September 10, 1913, by I. C. Allen. 1914.20 pp.

Technical Paper 74. Physical and chemical properties of the petroleums of California, by I. C. Allen, W. A. Jacobs, A. S. Crossfield, and R. R. Matthews. 1914. 38 pp., 1 fig.

Technical Paper 79. Electric lights for oil and gas wells, by H. H. Clark. 1914. 8 pp.

Teghntcal PaPer 104. Analysis of natural gas and illuminating gas by fractional distillation in a vacuum at low temperatures and pressures, by G. A. Burrell, F. M. Seibert, and I. W. Robertson. 1915. 41 pp., 7 figs. 
Technicar, Paper 117. Quantity of gasoline necessary to produce explosive vapont in sewers, by G. A. Burrell and H. T. Boyd. 1916. 18 pp., 4 figs.

Technical Paper 127. Hazards in handling gasoline, by G. A. Burrell. 1915. $12 \mathrm{pp}$.

Technical Paper 130. Underground wastes in oil and gas fields and methode of prevention, by W. F. McMurray and J. O. Lewis. 1916.31 pp., 3 pls., 8 figs.

Technical PaPer 131. The compressibility of natural gas at high pressures, by G. A. Burrell and I. W. Robertson. 1916.12 pp., 2 figs.

Technicat Paper 161. Construction and operation of a single-tube cracking furnace for making gasoline, by C. P. Bowie. 1916.16 pp., 10 pls.

\section{PUBLICATIONS THAT MAY BE OBTAINED ONIY THROUGH THE: SUPERINTENDENT OF DOCUMENTS.}

The editions for free distribution of the following Bureau of Mines publications are exhausted, but copies may be obtained by purchase from the Superintendent of Documents, Government Printing Office Washington, D.C., or can be consulted at public libraries. Prepays ment of the price is required and should be made in cash (exact amount) or by postal or express money order payable to the Superintendent of Documents.

The Superintendent of Documents is an official of the Government Printing Office and is not connected with the Bureau of Mines.

Bulletin 65. Oil and gas wells through workable coal beds; papers and discussions, by G. S. Rice, O. P. Hood, and others. $1913.101 \mathrm{pp} ., 1$ pl., 11 figs. 10 cents.

Bulietrin 114. Manufacture of gasoline and benzene-toluene from petroleum and other hydrocarbons, by W. F. Rittman, C. B. Dutton, and E. W. Dean, with a bibliography compiled by M. S. Howard. 1916.268 pp., 9 pls., 45 figs. 35 cents.

Technical Paper 26. Methods for the determination of the sulphur content of fuels, especially petroleum products, by I. C. Allen and I. W. Robertson. 1912, 13 pp., 1 fig. 5 cents.

Technical Paper 36. The preparation of specifications for petroleum products, by I. C. Allen. 1913.12 pp. 5 cents.

Technical Paper 51 Possible causes of the decline of oil wells, and suggested methods of prolonging yield, by L. G. Huntley. 1913. $32 \mathrm{pp}, 9$ figs. 5 cents.

Technical PaPer 53. Proposed regulations for the drilling of oil and gas wells, with comments thereon, by O. P. Hood and A. G. Heggem. 1913. 28 pp, 2 figs, 5 cents.

Technical Paper 109. Composition of the natural gas used in twenty-five cities, with a discussion of the properties of natural gas, by G. A. Burrell and G. G. Oberfell. 1915. $22 \mathrm{pp}$. 5 cents.

TeChnical PaPen 115. Inflammability of mixtures of gasoline vapor and air, by G. A. Burrell and H. T. Boyd. 1915. 18 pp, 2 figs.' 5 cents. 